\title{
The effects of energy paths and emission controls and standards on future trends in China's emissions of primary air pollutants
}

\author{
Y. Zhao ${ }^{1}$, J. Zhang ${ }^{2}$, and C. P. Nielsen ${ }^{3}$ \\ ${ }^{1}$ State Key Laboratory of Pollution Control \& Resource Reuse and School of the Environment, Nanjing University, 163 \\ Xianlin Ave., Nanjing, Jiangsu 210023, China \\ ${ }^{2}$ Jiangsu Provincial Academy of Environmental Science, 241 West Fenghuang St., Nanjing, Jiangsu 210036, China \\ ${ }^{3}$ Harvard China Project, School of Engineering and Applied Sciences, Harvard University, 29 Oxford St, Cambridge, MA \\ 02138, USA
}

Correspondence to: Y. Zhao (yuzhao@nju.edu.cn)

Received: 25 January 2014 - Published in Atmos. Chem. Phys. Discuss.: 24 March 2014

Revised: 1 July 2014 - Accepted: 17 July 2014 - Published: 1 September 2014

\begin{abstract}
To examine the efficacy of China's actions to control atmospheric pollution, three levels of growth of energy consumption and three levels of implementation of emission controls are estimated, generating a total of nine combined activity-emission control scenarios that are then used to estimate trends of national emissions of primary air pollutants through 2030. The emission control strategies are expected to have more effects than the energy paths on the future emission trends for all the concerned pollutants. As recently promulgated national action plans of air pollution prevention and control (NAPAPPC) are implemented, China's anthropogenic pollutant emissions should decline. For example, the emissions of $\mathrm{SO}_{2}, \mathrm{NO}_{\mathrm{x}}$, total suspended particles (TSP), $\mathrm{PM}_{10}$, and $\mathrm{PM}_{2.5}$ are estimated to decline 7, 20, 41, 34, and $31 \%$ from 2010 to 2030, respectively, in the "best guess" scenario that includes national commitment of energy saving policy and implementation of NAPAPPC. Should the issued/proposed emission standards be fully achieved, a less likely scenario, annual emissions would be further reduced, ranging from 17 (for primary $\mathrm{PM}_{2.5}$ ) to $29 \%$ (for $\mathrm{NO}_{\mathrm{x}}$ ) declines in 2015, and the analogue numbers would be 12 and $24 \%$ in 2030. The uncertainties of emission projections result mainly from the uncertain operational conditions of swiftly proliferating air pollutant control devices and lack of detailed information about emission control plans by region. The predicted emission trends by sector and chemical species raise concerns about current pollution control strategies: the potential for emissions abatement in key sectors may be declining due to the near saturation of emission con-
\end{abstract}

trol devices use; risks of ecosystem acidification could rise because emissions of alkaline base cations may be declining faster than those of $\mathrm{SO}_{2}$; and radiative forcing could rise because emissions of positive-forcing carbonaceous aerosols may decline more slowly than those of $\mathrm{SO}_{2}$ emissions and thereby concentrations of negative-forcing sulfate particles. Expanded control of emissions of fine particles and carbonaceous aerosols from small industrial and residential sources is recommended, and a more comprehensive emission control strategy targeting a wider range of pollutants (volatile organic compounds, $\mathrm{NH}_{3}$ and $\mathrm{CO}$, etc.) and taking account of more diverse environmental impacts is also urgently needed.

\section{Introduction}

Attributed to the large size and rapid growth of its economy and energy consumption, China's emissions of key primary atmospheric pollutants $\left(\mathrm{SO}_{2}, \mathrm{NO}_{\mathrm{x}}\right.$, and particle matter, $\left.\mathrm{PM}\right)$ are now estimated to be the highest in the world (Klimont et al., 2009; Lu et al., 2010; Lei et al., 2011a; Y. Zhao et al., 2013; B. Zhao et al., 2013). For example, China's $\mathrm{SO}_{2}, \mathrm{NO}_{\mathrm{x}}$ and $\mathrm{PM}_{2.5}$ emissions in 2010 were estimated at 27.7, 29.0, and $12.3 \mathrm{Tg}$ (Y. Zhao et al., 2013), accounting for 32, 31, and $31 \%$ of global emissions, respectively (Cofala et al., 2012). Such high emissions have led to poor air quality (Richter et al., 2005; van Donkelaar et al., 2010; Lin et al., 2010) and various environmental impacts including public health damage (WB and SEPA, 2007; Parrish and Zhu, 2009; Kan et 
al., 2012; Matus et al., 2012) and ecosystem acidification (Larssen et al., 2006; Zhao et al., 2009, 2011a).

To alleviate serious air pollution and the resulting environmental impacts, China has conducted a national strategy of energy conservation and emission reduction since 2005. Compulsory control measures are required in major economic sectors to limit fossil energy inputs and high emissions. These measures include replacement of small and inefficient plants or boilers with larger and energy-efficient ones in the power and some other heavy industrial sectors, installation of flue-gas desulfurization (FGD) systems at all newly built and many preexisting thermal power units, and staged implementation of more stringent emission standards on vehicles. The strategy has proven effective: national emissions of $\mathrm{SO}_{2}$ and $\mathrm{PM}$ are estimated to have declined gradually from 2005 to 2010 (Lu et al., 2011; Y. Zhao et al., 2013), partly confirmed by satellite and ground observations ( $\mathrm{Li}$ et al., 2010; Y. Zhao et al., 2013). Urban air quality, particularly leading up to and during major events (e.g., Beijing Olympics and Shanghai Expo), was improved due to incrementally tightened emission control and closures or relocations of major industrial plants (Wang et al., 2009, 2010). These measures, however, failed to restrain the growth of $\mathrm{NO}_{\mathrm{x}}$ emissions that are critical to formation of $\mathrm{PM}_{2.5}$ and $\mathrm{O}_{3}$ in the atmosphere. Episodes of extremely severe regional haze have occurred more frequently in recent years and have become a growing concern (Zhang et al., 2012a; Ma et al., 2012; Wang and Hao, 2012; L. T. Wang et al., 2014; Y. S. Wang et al., 2014), illustrating the need for expanded efforts in pollution control. Facing these circumstances, the government in succession issued new national ambient air quality standards (NAAQS) and a national action plan of air pollution prevention and control (NAPAPPC), requiring expanded and intensified efforts at emission abatement and air quality improvement. Since 2010, the national emission standards have been updated or proposed across a number of sectors, with much tighter emission limits overall.

The implementation of the above-mentioned measures and standards will significantly affect the source characteristics and emission level of the primary air pollutants that substantially determine regional air quality. The future trends in emissions of individual pollutant species and their interactions are important not only to understanding the physical and chemical cycles of air pollutants but also to evaluating the effectiveness and informing the design of policy strategies on air quality and even climate, using chemical transport models. A number of analysts have predicted future trends of China's air pollutant emissions (Ohara et al., 2007; Klimont et al., 2009; Xing et al., 2011a; B. Zhao et al., 2013; S. X. Wang et al., 2014). Most studies except very recent ones (e.g., S. X. Wang et al., 2014), however, have little detailed analyses on the effects of ongoing or upcoming control measures on the trends in emission factors (the emission levels per unit energy input or product output) by source type. In particular, the potential benefits of newly is- sued emission standards across sectors have not been well quantified, raising uncertainty of current estimates.

In this study, different scenarios of emission control and energy consumption in China are designed and the future emissions of $\mathrm{SO}_{2}, \mathrm{NO}_{\mathrm{x}}$ and $\mathrm{PM}$ in different size classes (total suspended particles (TSP), $\mathrm{PM}_{10}$, and $\mathrm{PM}_{2.5}$ ) are correspondingly estimated, including careful analyses of the changes in emission factors due to implementation of various control measures across sectors. It focuses on the period from 2010 to 2030, during which current plans anticipate most of China's megacities to meet the new NAAQS issued in 2012. Section 2 reviews the bottom-up emission inventory methodology and briefly describes the scenarios applied in this work. Section 3 is a thorough analysis of future trends of emission factors and their driving forces by sector, incorporating the latest information of emission control strategies and standards and data from domestic field measurements and investigations. Section 4 presents the predicted future emissions of primary air pollutants by scenario, and related discussions including the effectiveness of the emission control strategy, the implications of the interaction of different pollutant trends to ecosystems and climate forcing, and comparisons with other studies. Section 5 summarizes the study.

\section{Methods}

\subsection{The source categories of the emission inventory}

The research domain covers the 31 provinces of mainland China (see Fig. S1 in the Supplement). All main anthropogenic activities are included in the emission inventory framework. At the most aggregated scale, sources fall into four main sector categories: coal-fired power plants (CPP), all other industry (IND), transportation (TRA, including onroad and nonroad subcategories), and the residential and commercial sector (RES, including fossil fuel, biofuel use, and biomass open burning subcategories). IND is further divided into cement production (CEM), iron and steel plants (ISP), brick production (BRI), lime production (LIM), nonferrous metal production (NMP), and other industrial boilers and noncombustion processes (OIN), reflecting the structure of available data. The detailed methods of developing a bottom-up emission inventory for $\mathrm{SO}_{2}, \mathrm{NO}_{\mathrm{x}}$ and $\mathrm{PM}$ are described in previous studies (Zhao et al., 2011b; Y. Zhao et al., 2013). Generally, annual anthropogenic emissions of those pollutants are estimated by sector using Eq. (1):

$$
\begin{aligned}
E_{i, t} & =\sum_{k} \sum_{m} \sum_{n} \mathrm{AL}_{k, m, n, t} \times \mathrm{EF}_{i, k, m, t} \times R_{k, m, n, t} \\
& \times\left(1-\eta_{i, n, t}\right),
\end{aligned}
$$


where $i, k, m, n$ and $t$ stand for species, sector, fuel type, emission control technology and year, respectively; AL is the activity level, either energy consumption or industrial production; EF is the unabated emission factor; $R$ is the penetration rate of a given emission control technology; and $\eta$ is the removal efficiency of that technology.

\subsection{Scenarios and activity levels}

The year 2010, for which the authors estimated the emissions previously (Y. Zhao et al., 2013), is set as the base year, and annual emissions of $\mathrm{SO}_{2}, \mathrm{NO}_{\mathrm{x}}$, and $\mathrm{PM}$ are predicted for 2015, 2020, and 2030 based on different scenarios. To better understand the effects of activity levels (e.g., fuel consumption and industrial production) and emission control strategies on future emission trends, three levels of growth of energy and industrial production (explained later in this section) and three levels of implementation of emission controls (explained in detail in Sect. 3) are considered. This generates a total of nine combined activity-emission control scenarios evaluated for each of the target years. Table 1 summarizes the general assumptions about the energy trends and emission control polices and the derived scenarios.

Regarding activity levels, the principles behind scenarios of the International Energy Agency (IEA, 2012) are followed in this work, resulting in a Current Policy Scenario (CPS), a New Policy Scenario (NPS), and a 450 Scenario (450S). The assumptions of the three energy scenarios are explained in detail by IEA (2012). Briefly, as indicated in Table 1, NPS is identified as the "best guess" of future energy trends, taking account of the national energy policy commitments that have been announced (e.g., the plans to reduce fossil energy use and to reduce greenhouse gas emissions). In comparison, CPS is a conservative estimate that assumes those commitments will not be implemented and the national energy policy will not change in practice after 2010 . The $450 \mathrm{~S}$ is an aggressive scenario, which sets a Chinese energy path (as part of a global strategy) to limit the concentration of greenhouse gases in the atmosphere to approximately $450 \mathrm{ppm}$ (parts per million) of $\mathrm{CO}_{2}$ equivalent.

The current study applies most of the activity levels projected by IEA (2012) for all the scenarios, with some revisions for given emission sources based on more recent domestic information, as described below. Electric power generation is China's biggest coal-consuming sector, and since 2005 the government has implemented a series of measures to improve energy efficiency and to conserve coal use in the sector. Small and inefficient units have been scheduled for staged shutdown, first those less than $100 \mathrm{MW}$ electric (MWe) and then up to $200 \mathrm{MWe}$. In this work, two steps are used to predict future coal consumption by power plants. First, the coal use of "old" units (i.e., those built before the end of 2010) are estimated based on (1) the detailed power unit database compiled by the authors, which includes the parameter of coal use per unit generation of electricity (ex- pressed as gce $\mathrm{kWh}^{-1}$ ) plant by plant (Zhao et al., 2008), and (2) the government measures to phase out small units. These include assuming the retirement of all pulverized-coal units less than $100 \mathrm{MWe}$ and grate units for electricity generation only (i.e., not including combined heat and power units, CHP) by 2015, all units less than 200 MWe for electricity generation only by 2020 , and all CHP units less than 200 MWe by 2030 . These actions lead to total capacities of old units decreasing from 588 in 2015 to $555 \mathrm{GW}$ in 2030 , and coal consumption for these units from 1265 to $1179 \mathrm{Mt}$. (Note the average heat value of China's coal is $21 \mathrm{MJ} \mathrm{kg}^{-1}$; Zhao et al., 2010.) Second, the growth of "new" units (i.e., those built after 2010) is predicted based on the power plant construction plans in the State Grid. In the reference plans made in 2013, the average growth of national capacity is estimated at $50 \mathrm{GW} \mathrm{yr}^{-1}$ from 2010 to 2020 and $30 \mathrm{GW} \mathrm{yr}^{-1}$ from 2020 to 2030 (internal data, unpublished), and this assumption is applied in the CPS scenario in this work. Regarding NPS and 450S, the total thermal capacity is estimated to further decline for two reasons. First, the growth of national electricity demand would slow down, since China's electricity-consuming industry is expected to be approaching the peak, and thus the electricity consumption per unit Gross Domestic Production (GDP) would decrease in the future under the national policy of energy conservation (Wu, 2013). The second, more penetration of renewable power would be expected under the development plan of renewable energy by the National Energy Administration of China. The coal consumption paths are thus projected based on the capacity, average coal use per unit generation of electricity for advanced big units ( $320 \mathrm{gce} \mathrm{kWh}^{-1}$ ), and the average annual operation hours $(4700 \mathrm{~h}$, personal communication with L. Pan from China Electricity Council, 2013). Table 2 lists the total capacities and coal consumption of power plants projected in this work, compared with those by IEA (2012). In most cases (except 450S for 2020 and 2030), the IEA has less capacity but higher coal consumption, likely due to less consideration of improved coal combustion efficiency and reduced running hours for China's power units in the future.

The energy use (coal, oil, natural gas, and biofuel) of industry and residential and commercial sectors is taken from the IEA projection. It should be noted, however, that the total industry sector in this work is further divided into several subcategories to get a better understanding of the emission trends of those sources. Therefore, the coal consumption of CEM, ISP, LIM, and BRI, which depends on the output of relevant industrial products, must be estimated and then subtracted from the total industrial consumption to derive the coal use from other industrial boilers (OIN), for which sufficient independent data are lacking. The cement and steel production is projected by the IEA. The differences between scenarios are very small, e.g., the cement production in 2030 is estimated at 1972, 1954, and $1947 \mathrm{Mt}$ for CPS, NPS, and 450S, respectively. The IEA does not project lime and brick production, for which activity levels are also less developed 
Table 1. Basic principles and assumptions of energy path and emission control strategies for scenarios in this work.

\begin{tabular}{ll}
\hline Scenarios & Descriptions \\
\hline Energy and industrial production path \\
\hline CPS & $\begin{array}{l}\text { Current Policy Scenario (following IEA): conservative estimates with the assumption that national energy policy will } \\
\text { not change since 2010; modification on power and transportation sectors based on most recent domestic plans or } \\
\text { research. }\end{array}$ \\
NPS & $\begin{array}{l}\text { New Policy Scenario (following IEA): "best guess" of future energy trend including the national energy policy com- } \\
\text { mitments that have been announced; modification on power and transportation sectors based on most recent domestic } \\
\text { plans or research. }\end{array}$ \\
450S & $\begin{array}{l}\text { 450 Scenario (following IEA): the most aggressive scenario in terms of energy conservation and greenhouse emission } \\
\text { reduction; modification on power and transportation sectors based on most recent domestic plans or research. }\end{array}$ \\
\hline Emission control strategies & $\begin{array}{l}\text { Base case: conservative case that assumes unchanged emission control levels from 2010. } \\
\text { Reference case: "best guess" case including new improvements of emission control according to the national plan of } \\
\text { air pollution control action. }\end{array}$ \\
REF & $\begin{array}{l}\text { Fully implemented emission standard case: aggressive case that assumes the recently issued emission standards with } \\
\text { strict limits are satisfied by all the sources. }\end{array}$ \\
\hline
\end{tabular}

Table 2. Capacity and coal consumption of China's coal-fired power plants predicted by the IEA and this work.

\begin{tabular}{|c|c|c|c|c|c|c|c|c|c|}
\hline & & \multicolumn{4}{|c|}{ Capacity (GW) } & \multicolumn{4}{|c|}{ Coal consumption (Mt) } \\
\hline & & \multirow[t]{2}{*}{ IEA total } & \multicolumn{3}{|c|}{ This work } & \multirow[t]{2}{*}{ IEA total } & \multicolumn{3}{|c|}{ This work } \\
\hline & & & Old units & New units & Total & & Old units & New units & Total \\
\hline \multirow[t]{3}{*}{2015} & CPS & - & 588 & 406 & 993 & - & 1265 & 862 & 2127 \\
\hline & NPS & 885 & 588 & 402 & 989 & 2244 & 1265 & 854 & 2119 \\
\hline & $450 \mathrm{~S}$ & - & 588 & 350 & 938 & - & 1265 & 745 & 2010 \\
\hline \multirow[t]{3}{*}{2020} & CPS & 1080 & 579 & 597 & 1176 & 2644 & 1246 & 1269 & 2514 \\
\hline & NPS & 982 & 579 & 469 & 1048 & 2350 & 1246 & 997 & 2242 \\
\hline & $450 \mathrm{~S}$ & 859 & 579 & 420 & 1000 & 1938 & 1246 & 893 & 2139 \\
\hline \multirow[t]{3}{*}{2025} & CPS & - & 564 & 758 & 1322 & - & 1204 & 1610 & 2815 \\
\hline & NPS & 1025 & 564 & 542 & 1106 & 2428 & 1204 & 1151 & 2355 \\
\hline & $450 \mathrm{~S}$ & - & 564 & 244 & 808 & - & 1204 & 519 & 1723 \\
\hline \multirow[t]{3}{*}{2030} & CPS & 1358 & 555 & 897 & 1452 & 3254 & 1179 & 1906 & 3085 \\
\hline & NPS & 1079 & 555 & 591 & 1146 & 2478 & 1179 & 1256 & 2435 \\
\hline & $450 \mathrm{~S}$ & 668 & 555 & 119 & 674 & 1398 & 1179 & 252 & 1431 \\
\hline
\end{tabular}

in China's emission inventory literature (Zhao et al., 2011b). In this work, therefore, a rough estimate is made that the relative changes in lime and brick production in all scenarios follow those of cement in NPS. The coal consumption of those industrial processes is then calculated following the methods described in previous studies (Zhao et al., 2011b; 2012). In particular, it should be noted that coal consumption will be influenced by technology changes of emission sources, and that fact is considered in the activity level estimation by sector. For example, precalciner kilns consume $30 \%$ less coal than rotary ones for the same amount of cement production (Lei et al., 2011a), and the production of solid clay bricks requires twice the coal consumption of hollow ones (Zhao et al., 2012). The details of technology changes by sector will be explained in Sect. 3. Figure 1a summarizes the coal con- sumption by source and scenario for 2015, 2020, 2025 and 2030 estimated in this work.

The future oil consumption by the transportation sector is a big concern in China's energy research and has been addressed by a series of studies (Wang et al., 2006; Huo et al., 2012a; Ou et al., 2010; IEA, 2012). Compared to IEA (2012), Huo et al. (2012a) incorporated the latest data from investigations into the fuel economy and intensity of use of China's vehicles. Thus the oil consumption of on-road and rural vehicles (the vehicles that have much smaller engine power, lower designed maximum speed, and lower cost than lightduty diesel trucks, used for transportation of goods and passengers in countryside) in the high- and low-vehicle-growth scenarios by Huo et al. (2012a) are applied in this work, replacing the data of the original CPS and NPS by IEA (2012). 


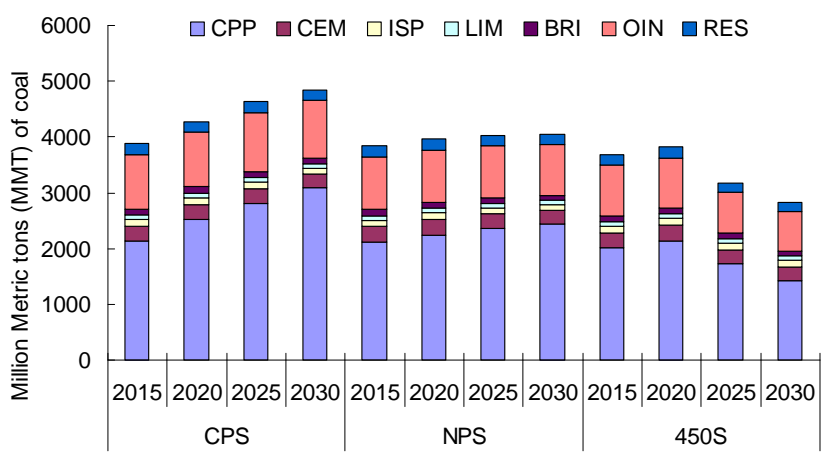

(a)

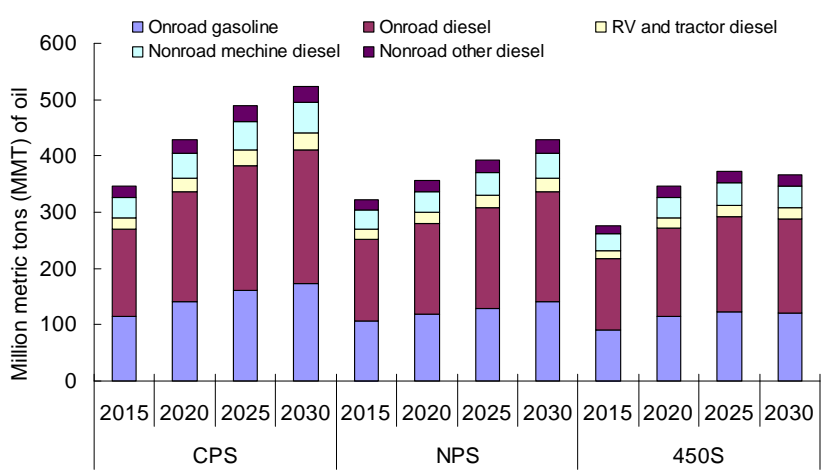

(b)

Figure 1. Projection of China's energy use for 2015, 2020, 2025 and 2030. (a) Coal consumption by sector and scenario; and (b) oil consumption of transportation by vehicle type and scenario.

For 450S, we keep the values of IEA (2012) as the most aggressive case for energy conservation. Regarding nonroad sources, the diesel consumption of railways and inland ships is adopted from the IEA; for other off-road equipment, the growth rates after 2010 are taken from an assumption in a recent domestic study $(\mathrm{Li}, 2011)$. Figure $1 \mathrm{~b}$ summarizes the future oil consumption from China's transportation sector by source and fuel type for different scenarios. With revisions based on the various aforementioned sources, the difference between CPS and NPS in this work tends to be larger than that in IEA (2012).

\section{Emission factor projection}

With such an expansive and complex emission category structure, the emission characteristics vary largely across both individual sources and sectors in China. Current and future emission control measures under the NAPAPPC and possible implementation of new emission standards for given sectors are expected to further change the penetration levels of different energy efficiency technologies and emission control devices, and thus to significantly affect the emission fac- tors of primary pollutants. Therefore, quantification of the potential trends of emission factors by source is crucial for projecting national emissions and is thereby the primary undertaking of this study. A base case (BAS), a reference case (REF), and a case of fully implemented emission standards (STD) are applied, as summarized in Table 1. In BAS, the emission control levels for each given technology are conservatively assumed unchanged in the future. This does not imply, however, that the penetration levels of advanced technologies and emission control devices for a whole subsector or sector will necessarily be the same as in the base year 2010. For example, the policy of replacing small power units with bigger and cleaner ones will undoubtedly raise the application of FGD systems for the power sector overall, even if the FGD application rates for small and large units remain at 2010 levels. REF is set as the "best guess" in terms of emission control strategies for the future. The proposed polices and possible new improvements in emission control according to the NAPAPPC are included in the scenario and their benefits are analyzed with currently available domestic information. As a plan issued by the central government, however, NAPAPPC itself does not specify the emission limits of different types of emission sources, and the actual emission levels do not necessarily satisfy the emission standards (issued or proposed), particularly for small and energy-inefficient industrial sources. The benefits of emission control measures may not be as sufficient as expected, attributed mainly to possible poor management and operation of air pollutant control devices for saving costs (Xu et al., 2011; Wang, 2013). STD, therefore, is a case assuming that the series of emission standards for sources across power and industrial sectors that China has issued or updated since 2010 will be strictly enforced (these standards are listed in Table S1 in the Supplement). Accordingly, STD is an aggressive control strategy and provides an ideal case exploring the potential of China's emission standards on emission abatement.

In summary, the trends of emission factors for NPS by source and scenario are illustrated in Fig. 2 (similar trends are projected for CPS and 450S, and they are not shown here for paper length but in Figs. S4 and S5 in the Supplement, respectively). In each panel of Fig. 2, the penetrations of various technologies are indicated on the left-hand vertical axis and the emission factors for BAS, REF, and STD on the righthand vertical axis (except for nonferrous metal production). The emission factor trends by sector are analyzed in detail below.

\subsection{Coal-fired power plants}

Since 2005, coal-fired power plants have been targeted for the most stringent emission controls, and the capacity shares of big power units ( $\geq 300 \mathrm{MWe})$ and FGD systems reached 78 and $86 \%$ at the end of 2010, respectively, leading to great $\mathrm{SO}_{2}$ and PM emission reductions (Y. Zhao et al., 2013). For $\mathrm{NO}_{\mathrm{x}}$ control, the capacity share of selective catalytic 


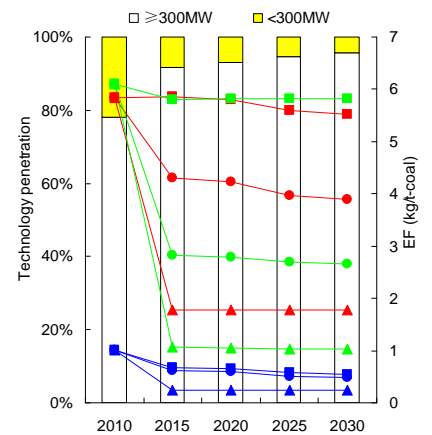

(a) Coal-fired power plants

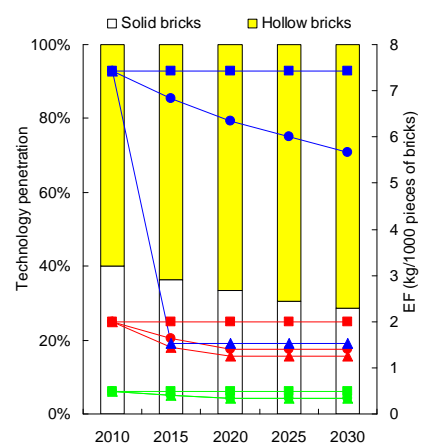

(d) Brick production

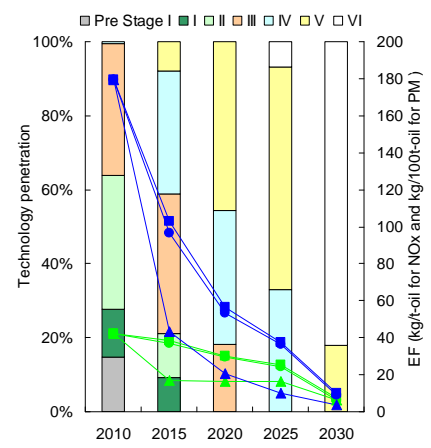

(g) Heavy-duty diesel vehicles

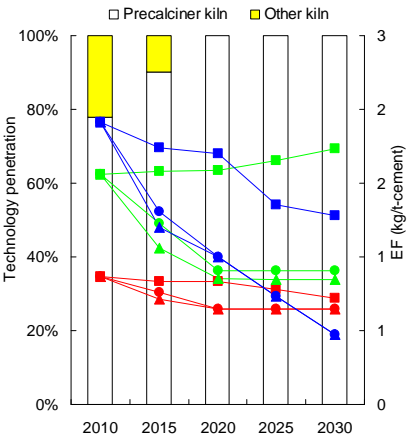

(b) Cement production

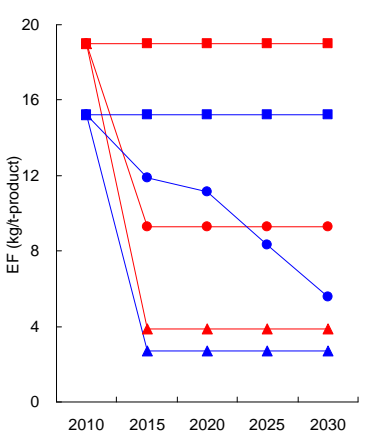

(e) Nonferrous metallurgy

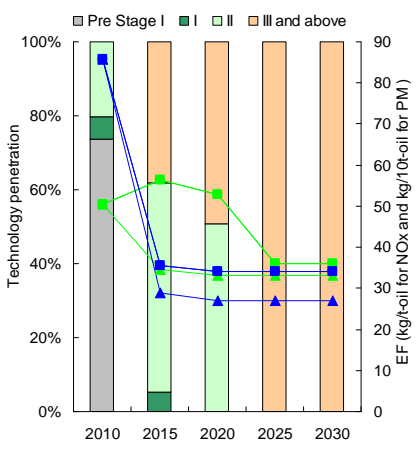

(h) Rural vehicles

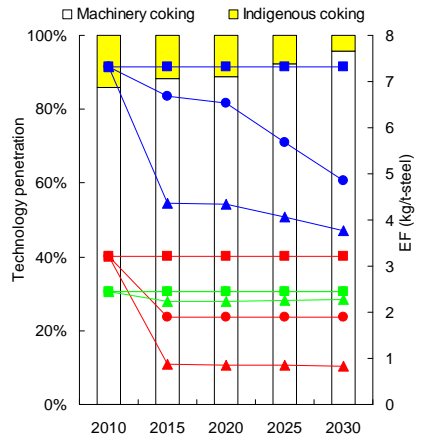

(c) Iron \& steel production

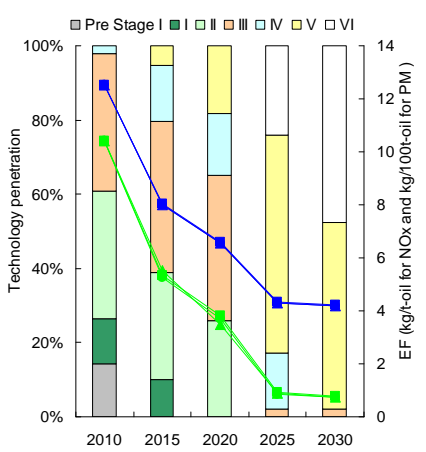

(f) Light-duty gasoline vehicles

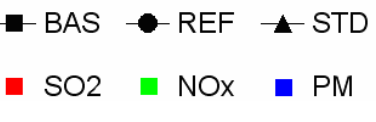

Figure 2. Projected trends in the penetration of technologies (color bars) and emission factors (symbolled lines) for typical sources in China from 2010 to 2030 . All panels are for the NPS activity scenario.

reduction (SCR) technology was still small at $13 \%$ in 2010, and another $100 \mathrm{GW}$ of SCR systems are under construction (Wang, 2013). The future emission trend depends largely on the penetration and removal efficiency of those technologies.

In BAS, the emission control strategies for the power sector in 2010 are assumed to continue; i.e., FGD systems will be required at all new power units and the national average of $\mathrm{SO}_{2}$ removal efficiency will remain $70 \%$, consistent with the results of a national survey of emission sources conducted in 2007 (Y. Zhao et al., 2013); no additional penetration of SCR is expected.

REF assumes a higher $(80 \%) \mathrm{SO}_{2}$ removal efficiency of FGD systems, due to improved operations, as indicated by recent investigation of power plants by the authors (Qiu et al., in preparation; see Table S2 in the Supplement). It also assumes SCR technologies are required for all newly built units and "old" ones (i.e., those built before the end of 2010) equal to or bigger than $300 \mathrm{MWe}$ in "key" regions (i.e., those with relatively concentrated industry and heavy pollution: eastern, north-central, and south-central China in this work, shown in Fig. S1 in the Supplement). For old units located in other areas, selective noncatalytic reduction (SNCR) technology is assumed, which has lower cost but also lower benefits of $\mathrm{NO}_{\mathrm{x}}$ control. The penetrations of different technologies by scenario and year are indicated in Fig. S2a in the Supplement. The average $\mathrm{NO}_{\mathrm{x}}$ removal efficiencies for SCR and SNCR are cautiously set at 60 and $50 \%$, respectively, less than those of full operation (Wang, 2013; personal 
communication with L. Pan from China Electricity Council, 2013). The lower removal efficiencies found in China than in developed countries result mainly from relatively poor operation and maintenance of installed technologies in order to save costs (Xu et al., 2011; Wang, 2013). For example, less ammonia used in SCR systems leads to lower removal efficiency of $\mathrm{NO}_{\mathrm{x}}$. For PM control, increased penetration of fabric filters (FF) or electrostatic-bag dust collectors is assumed, accounting for one-third of newly built unit capacity (see Fig. S3a for the trends of dust collector shares). All of the unabated emission factors and PM removal efficiencies for various types of dust collectors are obtained from the power plant emission factor database compiled by the authors (Zhao et al., 2010; see also Table S2 in the Supplement).

In STD, the new national emission standard for power plants issued in 2011 (GB 13223-2011) is applied to determine the emission factors of power units. Since the standard requires all of the units with different ages to satisfy the same emission limits at the beginning of 2014, the emission levels of $\mathrm{SO}_{2}, \mathrm{NO}_{\mathrm{x}}$, and $\mathrm{PM}$ are simply set to the standard limits of 200,200 , and $30 \mathrm{mg} \mathrm{m}^{-3}$, respectively, for 2015 and after. The emission factors $\left(\mathrm{kg} \mathrm{t}^{-1}\right)$ can then be derived following the method provided by Zhao et al. (2010). There are no specific limits for PM differentiated by size class; thus the mass fractions of $\mathrm{PM}_{10}$ and $\mathrm{PM}_{2.5}$ to $\mathrm{PM}$ are respectively assumed to be 0.81 and 0.45 , based on the field measurement results of power units with FF that can achieve the emission standard for TSP (Zhao et al., 2010). This method will also be applied for other source types in similar cases to determine the $\mathrm{PM}_{10}$ and $\mathrm{PM}_{2.5}$ mass fractions in STD. As shown in Fig. 2a, $\mathrm{NO}_{\mathrm{x}}$ emission factors are expected to decrease faster than the other two pollutants in REF and STD, reflecting the intended benefits of the country's $\mathrm{NO}_{\mathrm{x}}$ control measures in the future.

\subsection{Cement production}

At the end of 2010, China's cement production was dominated by precalciner kilns, the most energy-efficient technology, with its share exceeding $80 \%$ (Y. Zhao et al., 2013). Although the PM emission control performance of precalciner kilns is strong due to high penetration of FF (as shown in Fig. S3b in the Supplement), they are liable to generate more $\mathrm{NO}_{\mathrm{x}}$ emissions because of higher combustion temperatures than other types of kilns (Lei et al., 2011b). In BAS, all of the cement plants built after 2010 are assumed to use precalciner kilns but without the requirement of additional $\mathrm{NO}_{\mathrm{x}}$ controls, such as SCR/SNCR systems. In REF, all nonprecalciner kilns are assumed to be entirely shutdown by 2020 and the application of SNCR, with the $\mathrm{NO}_{\mathrm{x}}$ removal efficiency tentatively set at $50 \%$, is assumed for precalciner kilns in the aforementioned key regions after 2010. For kilns in other areas, low- $\mathrm{NO}_{\mathrm{x}}$ burners (LNB) are assumed to be used after 2015, with a lower $\mathrm{NO}_{\mathrm{x}}$ control effect (see the penetrations and removal efficiencies of those systems in Fig. S2b and Table S2 in the Supplement, respectively). Although the new emission standard for cement production has not yet been issued, a reduction in the $\mathrm{NO}_{\mathrm{x}}$ standard from 800 to $400 \mathrm{mg} \mathrm{m}^{-3}$ has been proposed (unpublished), leading to a reduced average emission factor of $1.2 \mathrm{~kg} \mathrm{NO}_{\mathrm{x}} \mathrm{t}^{-1}$ clinker. Based on the assumption that $1 \mathrm{t}$ of cement is produced from $0.72 \mathrm{t}$ of clinker, and that production of $1 \mathrm{t}$ of cement requires $125 \mathrm{~kg}$ of coal in precalciner kilns (Lei et al., 2011b), the $\mathrm{NO}_{\mathrm{x}}$ emission factor of the proposed limit is calculated at $6.8 \mathrm{~kg} \mathrm{t}^{-1}$ coal, and applied in STD of this work. Given the time needed for standard implementation, however, the old plants (defined as those built before the end of 2010) are assumed to satisfy the limit from 2020 on. All of the other unabated emission factors of $\mathrm{SO}_{2}, \mathrm{NO}_{\mathrm{x}}$, and PM and the PM removal efficiencies of dust collectors are taken from the country-specific database compiled by Lei et al. (2011b) and Zhao et al. (2011b). As seen in Fig. 2b, PM emission factors in REF and STD will keep declining due to additional penetration of FF, and the $\mathrm{NO}_{\mathrm{x}}$ limit of the proposed standard could be approached by use of SCR systems, even without full operation of the technology.

\subsection{Iron and steel production}

The emissions of the iron and steel industry include mainly gaseous and particle pollutant emissions from coking, sintering, and pig-iron production (in blast furnaces), and particle emissions from steel production (nearly $90 \%$ of which occurs in basic oxygen furnaces) and casting processes. In this work, we assume that the shares of various types of dust collectors would remain the same as those in 2010 for all processes in BAS, while new emission sources (reflected by the annual net growth of production) would apply the most advanced dust collectors that have already been deployed in analogous processes in REF; thus reflecting the effect of national policies to foster energy conservation and emission reduction. This assumption leads to a strong reduction of PM emission factors of iron and steel production in REF compared to those in BAS (Fig. 2c), and it will still hold for other industrial sources described in Sect. 3.4 (see Fig. S3c$\mathrm{k}$ in the Supplement for detailed information on penetration levels of various dust collectors in iron and steel production and other industrial processes). The unabated PM emission factors and removal efficiencies of dust collectors used in BAS and REF are taken from a previous study by the authors (Zhao et al., 2011b).

For coke production, the emission factors are updated to 1.0 (machinery coking ovens) $-4.3 \mathrm{~kg} \mathrm{t}^{-1}$ coke (indigenous ovens) for $\mathrm{SO}_{2}$ and $1.7 \mathrm{~kg} \mathrm{t}^{-1}$ coke for $\mathrm{NO}_{\mathrm{x}}$, based on recent domestic measurements (He, 2006; Huo et al., 2012b). The emission factors used for STD are determined based on the emission standard of pollutants for the coking chemical industry issued in 2012 (GB 16171-2012), which sets the same emission limits for 2015 and beyond for both newly built and existing ovens. For example, the $\mathrm{SO}_{2}$ concentration in 
flue gas is limited at $50 \mathrm{mg} \mathrm{m}^{-3}$ for machinery coking ovens, equal to $0.24 \mathrm{~kg} \mathrm{t}^{-1}$ coke based on an average of flue-gas volume at $5.0 \mathrm{~N} \mathrm{~m}^{3} \mathrm{~kg}^{-1}$ coke $(\mathrm{He}, 2006)$. The big reduction of emission factors from REF to STD would force the adoption of coke gas desulfurization in coke production to achieve sufficient removal efficiency. Similarly, the $\mathrm{NO}_{\mathrm{x}}$ and PM emission factors for machinery coking are calculated at 2.4 and $0.3 \mathrm{~kg} \mathrm{t}^{-1}$ coke, respectively.

Based on domestic measurements (AISGC, 2007; MEP, 2010), the $\mathrm{SO}_{2}$ and $\mathrm{NO}_{\mathrm{x}}$ emission factors for sintering processes were respectively estimated at 2.9 and $1.3 \mathrm{~kg} \mathrm{t}^{-1}$ product, as used in previous work (Y. Zhao et al., 2013) and in the BAS of this study. Under REF, the adoption of FGD systems is assumed for sintering, with the mean removal efficiency of $\mathrm{SO}_{2}$ conservatively set at $50 \%$ according to a limited field investigation by the authors in 2012 (unpublished). As a result, the $\mathrm{SO}_{2}$ emission factor for the whole iron and steel sector will be significantly reduced, as sintering is the main source of $\mathrm{SO}_{2}$ emissions in the sector (Fig. 2c). However, no extra measure for $\mathrm{NO}_{\mathrm{x}}$ control is assumed to be implemented. The STD emission factors are determined based on emission standards of air pollutants for sintering and pelletizing issued in 2012 (GB 28662-2012); i.e., 0.7, 0.8, and $0.25 \mathrm{~kg} \mathrm{t}^{-1}$ product for $\mathrm{SO}_{2}, \mathrm{NO}_{\mathrm{x}}$, and $\mathrm{PM}$, respectively.

For blast-furnace iron production, a national survey (MEP, 2010) determined the current averages of emission factors for $\mathrm{SO}_{2}$ and $\mathrm{NO}_{\mathrm{x}}$ as 0.15 and $0.20 \mathrm{~kg} \mathrm{t}^{-1}$ iron, respectively. These factors were applied in previous work (Y. Zhao et al., 2013) and used in the BAS and REF cases of this study. Regarding STD, domestic plants with the highest energy efficiencies and most advanced emission control technologies were investigated (SSC, 2007). The report determined the emission factors at $0.05,0.10$, and $0.12 \mathrm{~kg} \mathrm{t}^{-1}$ iron for furnace $\mathrm{SO}_{2}, \mathrm{NO}_{\mathrm{x}}$, and $\mathrm{PM}$. These values were used as the emission standards for air pollutants from the iron smelting industry (GB 28663-2012). The mass fraction of $\mathrm{PM}_{10}$ and $\mathrm{PM}_{2.5}$ in STD are estimated based on the removal efficiencies of FF by particle size. The fugitive PM emissions, however, are difficult to quantify for STD and are assumed to be the same as REF. In steel production, very little $\mathrm{SO}_{2}$ or $\mathrm{NO}_{\mathrm{x}}$ is emitted from basic oxygen/electric furnaces. According to a national investigation (BGC, 2007), the PM emission levels of big plants with improved emission control are approximately $60 \%$ lower than the national average and set as the limit of the emission standard for the steel smelting industry (GB 28664-2012) and thereby assumed as the emission factor of STD in this work.

The casting process also generates particles. However, there is no clear emission standard or other information about emission control for the process yet. Therefore we assume the same PM emission factors in STD as those in REF of this work.

\subsection{Other industrial sources}

Emission factors of brick production, lime production, nonferrous metal smelting, and other boilers are described in this section.

Coal combustion in kilns is the main source of $\mathrm{SO}_{2}$ and $\mathrm{NO}_{\mathrm{x}}$ emissions in brick production. In the base year 2010 , solid bricks accounted for approximately $40 \%$ of total production and the national average of coal consumption per 10000 bricks was estimated at $0.88 \mathrm{t}$ equivalent (tce), based on the coal consumption rates of 1.3 tce/10000 solid clay bricks and 0.6 tce $/ 10000$ hollow ones (Xu and Wang, 2007; Zhao et al., 2012). According to a national survey of brick kilns (CRAES, 2009), the average $\mathrm{SO}_{2}$ and $\mathrm{NO}_{\mathrm{x}}$ emission levels are 345 and $160 \mathrm{mg} \mathrm{m}^{-3}$ in flue gas, respectively. The emission factors can then be calculated at 17 and $8.0 \mathrm{~kg} / 10000$ bricks based on the average flue-gas amount of $\sim 50000 \mathrm{~nm}^{3} / 10000$ bricks, i.e., 14.0 and $6.5 \mathrm{~kg} \mathrm{t}^{-1}$ coal, respectively. We assume the fraction of solid bricks is unchanged in BAS, and thus the $\mathrm{SO}_{2}$ and $\mathrm{NO}_{\mathrm{x}}$ emission factors remain the same as in 2010. In REF, however, the use of solid bricks is assumed to be strictly limited at the 2010 level and the coal consumption per 10000 bricks decreases accordingly, leading to a lower level of $\mathrm{SO}_{2}$ and $\mathrm{NO}_{\mathrm{x}}$ emission levels, as shown in Fig. 2d. Regarding PM, as mentioned in Sect. 3.3, the penetration of various types of dust collectors and thereby the emission factors for BAS are assumed the same as that in 2010 (Y. Zhao et al., 2013). In REF, more application of wet scrubbers with higher PM removal efficiency than cyclones is assumed, resulting in a considerable reduction of PM emission factors. For STD, as proposed in the new standard (CRAES, 2009), the PM limit is set roughly $80 \%$ lower than the current level, while no significant reduction is required for $\mathrm{SO}_{2}$ or $\mathrm{NO}_{\mathrm{x}}$. The mass fractions of $\mathrm{PM}_{10}$ and $\mathrm{PM}_{2.5}$ are determined based on the size-dependent removal efficiencies of wet scrubbers.

Until now there is little information about nor any proposed standard for emission control in lime production. The emission factors for $\mathrm{SO}_{2}$ and $\mathrm{NO}_{\mathrm{x}}$ in base year 2010 are applied for all scenarios in this work. PM emission factors for BAS remain the same as the base year, while they are expected to decline in REF and STD, attributed to increased penetration of FF with higher PM removal efficiencies.

Nonferrous metals include production of copper $(\mathrm{Cu})$, lead $(\mathrm{Pb})$, zinc $(\mathrm{Zn})$, electrolytic aluminum $(\mathrm{Al})$ and alumina that generate $\mathrm{SO}_{2}$ and $\mathrm{PM}$ emissions. For $\mathrm{SO}_{2}$, a national survey was conducted (MEP, 2010); based on which the current level, the emission limit for existing sources, and the limit for newly built sources, are determined and applied for emission factors of BAS, REF, and STD in this work, respectively. For $\mathrm{Cu}$ smelting, as an example, the current average level of fluegas $\mathrm{SO}_{2}$ concentration, the limit for existing sources, and the limit for the new sources were estimated at 2116, 960, and $400 \mathrm{mg} \mathrm{m}^{-3}$. The emission factors of BAS, REF, and STD can then be accordingly calculated at 49,22 , and $9 \mathrm{~kg} \mathrm{t}^{-1}$ 
$\mathrm{Cu}$, respectively, based on the average flue-gas amount of $23000 \mathrm{~N} \mathrm{~m}^{3} \mathrm{t}^{-1} \mathrm{Cu}$ (CRAES, 2007; MEP, 2010). The PM emission factors of BAS are assumed the same as in the base year (Y. Zhao et al., 2013) and those of REF are expected to decrease due to more application of advance dust collectors. For STD, the newly issued emission standards for nonferrous metals (GB 25465-2010; GB 25466-2010; and GB 254672010) require a significantly enhanced control, and the extremely low limits imply the need to apply the most effective dust collectors like FF. Compared to BAS, roughly $80 \%$ of emission abatement is required by the standards for both $\mathrm{SO}_{2}$ and PM (Fig. 2e).

For other industrial coal-combustion boilers, the emission factors in BAS are assumed to be the same as in 2010. In REF and STD, FGD and LNB are expected to be used for newly built sources following the instructions of the NAPAPPC with the average $\mathrm{SO}_{2}$ and $\mathrm{NO}_{\mathrm{x}}$ removal efficiencies of 70 and $30 \%$, respectively. Figure S2c in the Supplement shows the penetrations of those technologies in detail. For PM control, similar to other industrial sources, the new sources are expected to be installed with wet scrubbers, leading to reduced PM emission factors. The emission factors of oil and gas boilers are assumed to remain the same as in 2010 for all the scenarios.

\subsection{Transportation}

China's new on-road vehicles have been required to meet staged emission standards (stages I-IV, equivalent to Euro IIV) since 1999. Based on the vehicle population growth and assumed vehicle lifetimes by type, the fleet compositions by control stage can be determined and thus the emission factors by type can be calculated as described in previous work (Zhao et al., 2012). Therefore the times of implementation of stricter emission standards (e.g., stage V or VI) in the future are crucial for projecting emission levels in transportation.

Although stages I-III were implemented roughly at the same time across the country (except for certain megacities like Beijing), the standards under latter stages may come into operation asynchronously by province/region, making the projection quite difficult and uncertain. In BAS, a conservative assumption is made in that stages IV and $\mathrm{V}$ for on-road vehicles would take effect as of 2013 and 2016 in the entire country, respectively, while those implementation years are expected to move forward to 2011 and 2014 in REF and STD for selected provinces with large and dense vehicle populations, including Tianjin in north-central China, Shanghai, Jiangsu and Zhejiang in eastern China, and Guangdong in south-central China (see Fig. S1). It should be also noted that certain nonroad sources are required as well to gradually meet standards but no differences are assumed between the scenarios of this work. Table S3 in the Supplement summarizes the time schedule of implementation of emission standards for China's transportation sector.
In previous work, the on-road measurements of $\mathrm{NO}_{\mathrm{x}}$ and $\mathrm{PM}_{2.5}$ emission factors for China's vehicles by type and control stage were thoroughly investigated and the emission factors were obtained in real-life operating conditions and applied in emission inventory development (Y. Zhao et al., 2013). In this work, most recent domestic studies (Fu et al., 2012; Huo et al., 2012c) are included to update the emission factor database, and those updated emission factors are applied in the BAS and REF scenarios. For STD, an aggressive assumption is made in that standard limits would be strictly satisfied, with little effect of vehicle deterioration from poor inspection and maintenance considered. This is of course an ideal case providing minimum emission levels for a given vehicle population with a fixed fleet composition. Figure $2 \mathrm{f}-\mathrm{h}$ show the fleet composition and changes in emission factors for typical vehicle types. Faster reduction of $\mathrm{NO}_{\mathrm{x}}$ emission factors is expected for light-duty vehicles (as they already have relatively low PM emissions factors), while a faster reduction of PM is expected for heavy-duty diesel and rural vehicles.

\subsection{Residential and commercial combustion}

For the residential and commercial sector, very few measures or standards of emission control have been announced or are expected to be implemented in the near future. In most cases, therefore, the emission factors for all of the scenarios are assumed unchanged from those in 2010, including for coal, oil, gas, and biofuel combustion. One exception is the coal combustion in REF and STD, in which the share of small-coal stoves is assumed to decrease due to penetration of more district heating with advanced grate boilers, resulting in reduced PM emission factors. Most recent domestic field studies ( $\mathrm{H}$. Zhang et al., 2012; Shen et al., 2013) are included to update the emission factors used in previous work (Y. Zhao et al., 2013).

\section{Results and discussion}

\subsection{Emission trends by scenario}

The national emissions in 2015, 2020, 2025 and 2030 are summarized by the scenario in Table 3 , and the emissions in 2010 (Y. Zhao et al., 2013) are provided as well for comparison. The sector distributions of emissions are indicated in Fig. 3 for scenarios with different emission control levels BAS, REF, and STD under a common energy and industrial production trend, the best-guess NPS. Compared to energy and industrial production, the emission control strategies tend to have more effect on the estimated future trends of emissions for all of the concerned pollutants.

Under the BAS scenarios representing current emission control strategies, national $\mathrm{SO}_{2}$ emissions are estimated to increase compared to 2010, except for the case of $450 \mathrm{~S}$ in 2030. Since $\mathrm{SO}_{2}$ emissions are mainly from fossil fuel 


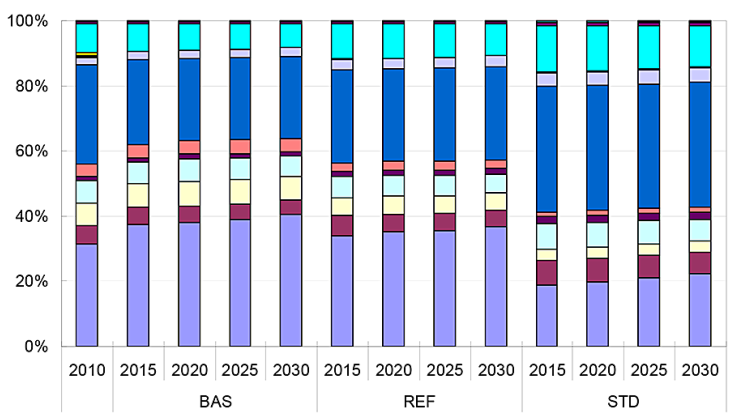

(a)

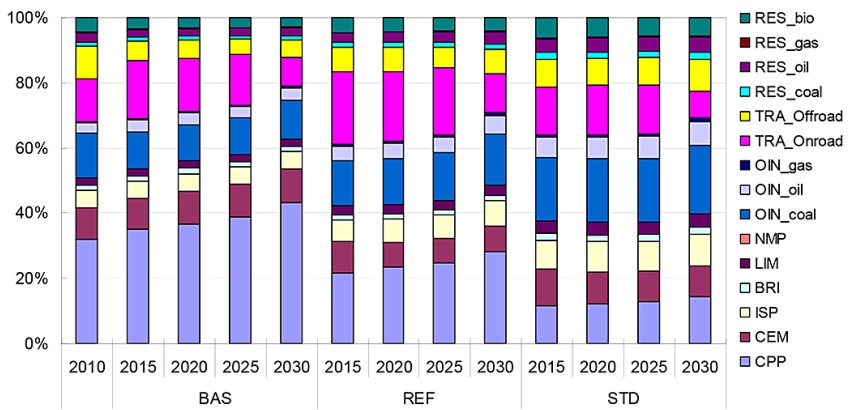

(b)

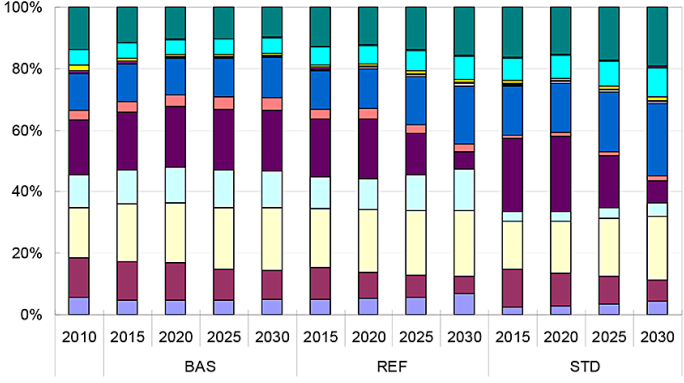

(c)

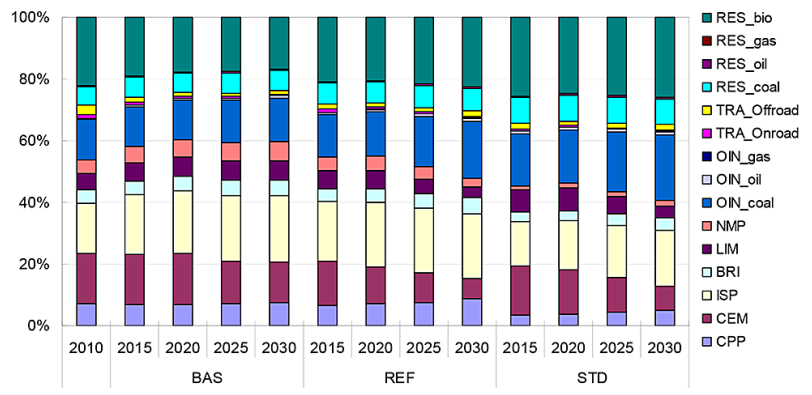

(d)

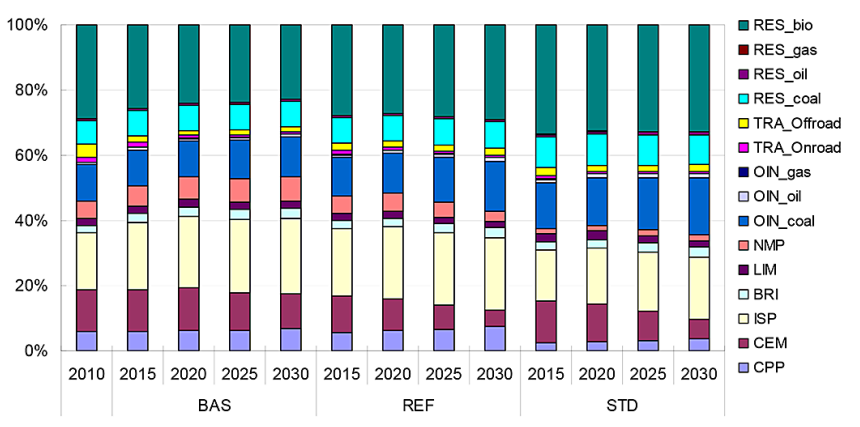

(e)

Figure 3. Shares of China's anthropogenic emissions by source for 2015, 2020, 2025 and 2030. Values are for the NPS activity scenario and three emission control levels: BAS, REF, and STD. (a) $\mathrm{SO}_{2}$; (b) $\mathrm{NO}_{\mathrm{x}}$; (c) $\mathrm{PM}$; (d) $\mathrm{PM}_{10}$; and (e) $\mathrm{PM}_{2.5}$.

combustion, the energy path would have a clear impact on future $\mathrm{SO}_{2}$ trends. Following the conservative CPS path of energy use and industrial production, $\mathrm{SO}_{2}$ emissions would reach $38.1 \mathrm{Tg}$ in 2030 , while they may decrease by $33 \%$ to 25.7 Tg in the aggressive $450 \mathrm{~S}$ path. With enhanced emission control (REF scenarios), no significant growth of $\mathrm{SO}_{2}$ emissions is expected after 2010, attributed mainly to the broader use and improved operation of FGD systems. The emissions of the power sector and iron and steel production, for example, are estimated to decrease by 30 and $41 \%$, respectively, from the BAS to the REF case under a common NPS energy path in 2030. As a result, the national total $\mathrm{SO}_{2}$ emissions of REF scenarios are estimated to range $21-24 \%$ lower than those of BAS ones. Should emission standards be fully implemented (STD scenarios), the emissions would be fur- ther reduced by $23-26 \%$. Shown in Fig. 3a, clear changes in sector contributions of emissions exist by year and scenario. Power plants are identified as the biggest contributor in BAS and REF cases, with the shares of emissions increasing slowly from 2015 to 2030. In STD, the shares of the power sector decrease by approximately $20 \%$, spotlighting the importance of other industrial boilers as significant emission sources that should be of greater concern. A modest reduction of emissions is found for residential and commercial activities, due to the gradually reduced coal consumption for the sector. 
Table 3. Projected national emissions of anthropogenic $\mathrm{SO}_{2}, \mathrm{NO}_{\mathrm{x}}$, and $\mathrm{PM}$ for 2015, 2020, 2025 and 2030 by scenario (unit: Gg). The emissions of 2010 (Y. Zhao et al., 2013) are listed as well for comparison.

\begin{tabular}{rlrrrrrrrrrrrrr}
\hline & & 2010 & \multicolumn{3}{c}{2015} & & & 2020 & & & 2025 & & 2030 \\
\hline & & & BAS & REF & STD & BAS & REF & STD & BAS & REF & STD & BAS & REF & STD \\
$\mathrm{SO}_{2}$ & CPS & 27714 & 33838 & 27046 & 20172 & 36302 & 28118 & 20683 & 37791 & 29104 & 21684 & 38097 & 28917 & 21258 \\
& NPS & & 33360 & 26792 & 19935 & 34365 & 26885 & 19954 & 33764 & 26245 & 19671 & 33108 & 25676 & 19202 \\
& $450 S$ & & 32412 & 26234 & 19579 & 33414 & 26316 & 19577 & 28191 & 21993 & 16552 & 25678 & 20213 & 15516 \\
\hline NO $_{\mathrm{x}}$ & CPS & 28816 & 35939 & 28221 & 20061 & 38560 & 28726 & 20646 & 40055 & 28856 & 21144 & 38573 & 26225 & 19280 \\
& NPS & & 35125 & 27511 & 19613 & 35533 & 26699 & 19323 & 35101 & 25575 & 18933 & 32803 & 22933 & 17361 \\
& $450 S$ & & 33215 & 26074 & 18827 & 34437 & 26010 & 18883 & 29849 & 22574 & 17020 & 24899 & 18597 & 14838 \\
\hline PM & CPS & 28746 & 29952 & 26911 & 21261 & 30970 & 26025 & 20812 & 29099 & 21783 & 17545 & 27615 & 17793 & 14373 \\
& NPS & & 29724 & 26699 & 21060 & 30561 & 25673 & 20505 & 28163 & 20938 & 16812 & 26575 & 16854 & 13607 \\
& $450 S$ & & 29469 & 26472 & 20856 & 30319 & 25460 & 20306 & 26936 & 19850 & 15810 & 25168 & 15630 & 12523 \\
\hline PM $_{10}$ & CPS & 16990 & 17241 & 15746 & 12926 & 17488 & 15144 & 12518 & 16438 & 13456 & 11426 & 15628 & 11789 & 10251 \\
& NPS & 17087 & 15599 & 12789 & 17178 & 14876 & 12296 & 15790 & 12874 & 10943 & 14890 & 11129 & 9739 \\
& $450 S$ & & 16896 & 15426 & 12641 & 17005 & 14721 & 12157 & 14930 & 12107 & 10262 & 13860 & 10233 & 8985 \\
\hline PM $_{2.5}$ & CPS & 12212 & 12431 & 11525 & 9537 & 12479 & 11104 & 9201 & 11800 & 9978 & 8501 & 11219 & 8853 & 7751 \\
& NPS & & 12318 & 11419 & 9440 & 12251 & 10905 & 9045 & 11358 & 9585 & 8193 & 10713 & 8402 & 7426 \\
& $450 S$ & & 12174 & 11288 & 9333 & 12128 & 10795 & 8949 & 10777 & 9070 & 7755 & 10004 & 7791 & 6942 \\
\hline
\end{tabular}

The $\mathrm{NO}_{\mathrm{x}}$ emission trends in BAS cases would be dominated by fossil fuel use, and the emissions in 2030 are estimated at 38.6, 32.8 and $24.9 \mathrm{Tg}$ (i.e., 134,114 , and $86 \%$ of emissions in 2010) for CPS, NPS, and 450S cases, respectively. In the REF scenarios, significant benefits would be achieved from the penetration of SCR and LNB technologies in power and industrial sectors. Even with a conservative estimate of the national average $\mathrm{NO}_{\mathrm{x}}$-removal efficiencies, the power and cement sectors would see their emissions reduced by 54 and $48 \%$ respectively from the BAS to the REF case in 2030 under a common NPS energy path, leading to a $20 \%$ reduction of the national total emissions from 2010 to 2030 , i.e., from 28.8 to $22.9 \mathrm{Tg}$. In STD, the very aggressive emission standard for power plants would limit emissions of the sector to 1591 (for $450 \mathrm{~S}$ ) and to $3079 \mathrm{Gg}$ (for CPS) in 2030, approximately $80 \%$ lower than the levels in BAS cases. In contrast to power plants, the share of transportation would not significantly decrease for any of the scenarios until 2030, as shown in Fig. 3b. For heavy duty vehicles, the biggest sources of transportation $\mathrm{NO}_{\mathrm{x}}$ emissions, current on-road tests failed to find a statistically significant improvement of $\mathrm{NO}_{\mathrm{x}}$ emission factors as emission standards became more stringent (Wu et al., 2012). Similar results were also found for rural vehicles (Yao et al., 2011). Stage III and IV vehicles are thus believed to have emission levels close to those of stages I and II, most likely attributable to similar driving patterns and diesel fuel quality. Additionally, the $\mathrm{NO}_{\mathrm{x}}$ emissions from vehicles will be relatively difficult to reduce in the near future.

Coming largely from industrial processes, PM emissions are projected to be less affected by the energy path than $\mathrm{SO}_{2}$ or $\mathrm{NO}_{\mathrm{x}}$, since the output levels of the main industrial products are estimated to be similar among different energy scenarios. A considerable reduction in emissions is expected from the further penetration of advanced dust collectors at industrial sources under the national action plan of air pollution control. In the NPS-REF case, as an example, the PM emissions from cement, iron and steel, brick, and nonferrous metal production in 2030 are estimated to decrease by 74 , 22,24 , and $56 \%$ compared to 2010 , respectively, leading to a decline of TSP emissions from 28.7 to $16.9 \mathrm{Tg}$ during the period. Under the implementation of issued or proposed standards (the STD case), PM emissions from brick and nonferrous metal production in 2030 would be further reduced by 73 and $52 \%$, respectively, compared to the REF case. The benefit of emission standards for iron and steel production, however, is limited, since the fugitive dust requirement by the standards, expressed as the ambient dust concentration near the plant, cannot be directly accounted as an emission abatement benefit. Regarding PM by size, the shares of finer particles would grow as more stringent control reduces PM overall (chiefly through reduction of coarser particles), raising the difficulty of further reductions because smaller primary particles are more difficult to abate. The mass fractions of $\mathrm{PM}_{2.5}$ to TSP, as an example, are estimated to increase from $40 \%$ in BAS cases to $55 \%$ in STD cases for 2030. Shown in Fig. 3ce, certain industrial sources (e.g., brick and lime production) play important roles in TSP emissions but contribute much less to finer particles. Transportation and residential combustion of fossil fuels and biofuel are thus identified as more important sources of fine particles, particularly as control of industrial emission continues to progress in the future. 


\subsection{Limitations}

In this work, the benefits of national emission control strategies and the most recent emission standards are quantified, although there are still considerable uncertainties. $\mathrm{The}^{\mathrm{NO}_{\mathrm{x}}}$ emission levels from coal combustion, for example, are influenced by many factors including coal quality, burner types, and combustion operation (Zhao et al., 2010). The actual removal efficiencies of SCR and SNCR systems can vary significantly between individual plants, particularly when those plants are required to reach or even approach a specific emission standard. It is thus difficult to determine accurate removal efficiencies for the country, even by the power companies themselves (personal communication with L. Zhu from China Guodian Corporation, one of the largest power companies in China, 2013), and the national averages derived from limited tests and expert judgment had to be applied in this work. Similarly, due to a lack of information regarding individual small boilers, the NAPAPPC could not be followed precisely in this work, and local plans for air pollution control are being issued, or will be issued, subsequent to the national one, particularly in provinces with heavy pollution. This leads to divergent emission controls by region in practice. Finally, uniform emission standards have been set in STD for a given type of emission sources due to a lack of detailed individual plant data, resulting in possible overestimates of emissions from plants that actually have lower emission levels than the standards. All of these facts imply a need for further investigation of individual plants in key regions and sectors, to better understand the future trends of emission factors for China's air pollutants. Besides emission control levels, the activity levels (i.e., energy consumption and industrial production) also play significant roles on future emission trends. In this work, the energy projection by IEA (2012) is mainly applied with revisions for specific sources combining the latest information. The future energy trends, however, would be significantly independent of national and local energy policies, which could not be fully followed or predicted at the current stage. Thus the estimated emissions based on current energy projections should be interpreted cautiously and necessary revisions are strongly suggested when new energy policies become available.

Because of the above-mentioned limitations, there are discrepancies between the projected emissions in this work and the national emission targets that are intended to be achieved through full implementation of the emission control strategies, particularly in the near future. For example, the country has announced that the annual emissions of $\mathrm{SO}_{2}$ and $\mathrm{NO}_{\mathrm{x}}$ in 2015 will be reduced respectively by 8 and $10 \%$ compared to those in 2010, while much smaller abatement is found following the NPS-REF path (the "best-guess" case) in this work. To further understand the recent trends of emissions, the vertical column density (VCD) of tropospheric $\mathrm{NO}_{2}$ from the Ozone Monitoring Instrument (OMI) are used as indirect evidence. The annual $\mathrm{NO}_{2} \mathrm{VCD}$ over mainland China from 2010 to 2013 is calculated and mapped in Fig. S4 in the Supplement based on the monthly data with resolution of $0.125^{\circ} \times 0.125^{\circ}$ retrieved by the Royal Netherlands Meteorological Institute (Boersma et al., 2007; http://www.temis.nl/ airpollution/no2col/no2regioomimonth_v2.php). Since the data in November and December of 2013 were unavailable at the time of writing, 10-month (from January to October) averages instead of annual means are used for interannual comparisons. Although the 10-month mean $\mathrm{NO}_{2} \mathrm{VCD}$ reached a peak in 2011 and started to decline afterwards, the mean VCDs in 2012 and 2013 are still 13 and $8 \%$ higher than those in 2010, implying incomplete implementation of the emission controls and illustrating the difficulty in national emission reduction. Moreover, as shown in Fig. S4, clear regional differences are found in VCD trends. Compared to megacity areas (e.g., the Yangtze River delta region), bigger growth in VCDs from 2010 to 2013 are found in less-developed areas, such as north-central and south-central China, consistent with Zhang et al. (2012b). These limited satellite-retrieved VCD data thus reconfirm (1) the importance of careful investigation of emission control implementation to improve the accuracy of emission projections and to ensure the success of national polices, and (2) the necessity of emission trend analysis by region.

Besides the species concerned in this work, some other pollutants including volatile organic compounds (VOCs), $\mathrm{NH}_{3}$ and $\mathrm{CO}$ are confirmed to play important roles in atmospheric chemistry and pollution formation in China (Xing et al., 2011b; Wang et al., 2011; Chen et al., 2009). Those pollutants come largely from industrial and agricultural processes with big diversities of manufacturing technologies and pollution control levels. Much larger uncertainties of emissions were found for them than for $\mathrm{SO}_{2}$ and $\mathrm{NO}_{\mathrm{x}}$ that come more from big energy-related sources (Zhang et al., 2009). Till now they are relatively less stressed by the current emission control strategies or standards compared to $\mathrm{SO}_{2}, \mathrm{NO}_{\mathrm{x}}$ and $\mathrm{PM}$, resulting in even higher uncertainty of emission projection for them. Therefore, the study on future trends of emissions for those species is strongly suggested once the improved and more specific emission control policies and standards become available.

\subsection{Comparisons with other studies}

A series of studies focuses on projections and future trends of China's primary air pollutants. Earlier studies (e.g., Streets and Waldhoff, 2000, and Klimont et al., 2001) were based on relatively conservative projections of energy growth and emission control strategies, and thus are not included in the comparisons of this work. Since 2005, three main groups or research programs have conducted thorough analysis of Chinese future emission trends using different scenarios: the Regional Emission inventory in ASia (REAS; Ohara et al. 2007), the International Institute for Applied System Analysis (IIASA; Amann et al. 2008, and Cofala et al. 2012), 


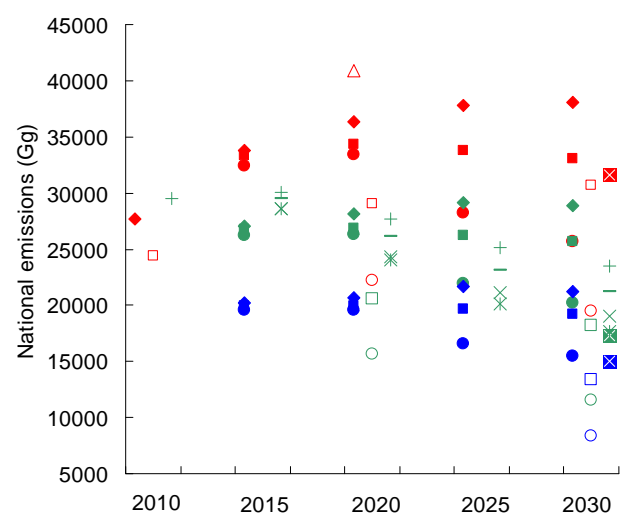

(a) $\mathrm{SO}_{2}$

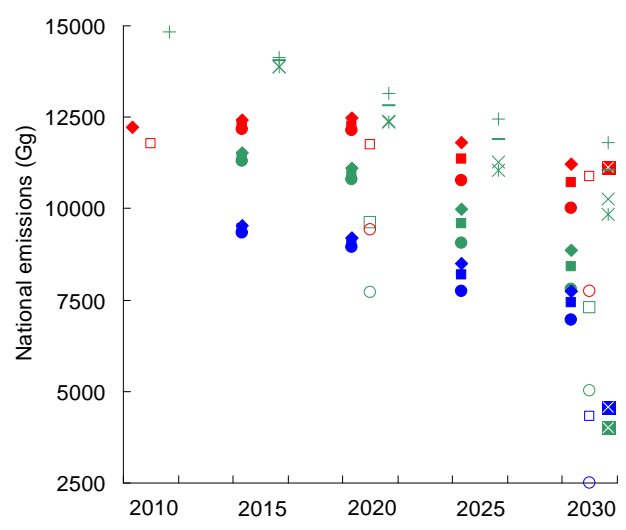

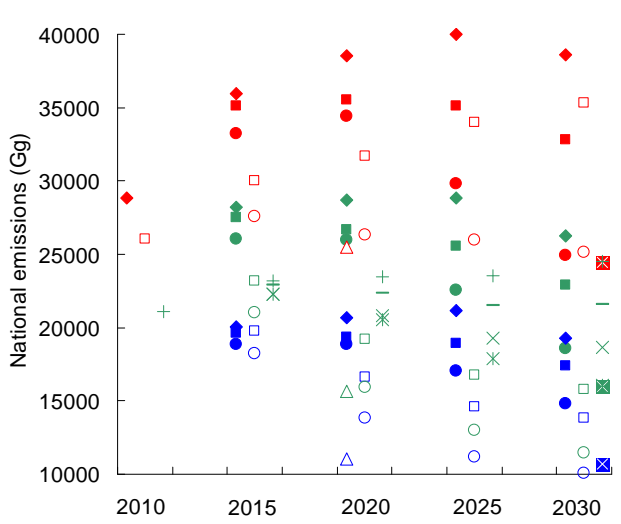

(b) $\mathrm{NO}_{\mathrm{x}}$

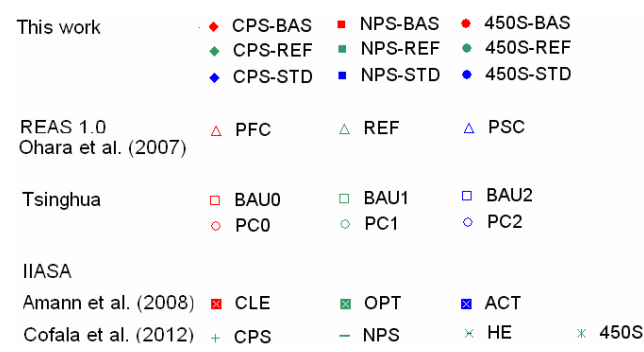

(c) $\mathrm{PM}_{2.5}$

Figure 4. Comparisons of projected Chinese emissions between this work and other studies. (a) $\mathrm{SO}_{2}$, (b) $\mathrm{NO}_{\mathrm{x}}$ and (c) $\mathrm{PM}_{2.5}$.

and Tsinghua University (Xing et al., 2011a, B. Zhao et al., 2013, and S. X. Wang et al., 2014). Ohara et al. (2007) set three cases to evaluate China's $\mathrm{SO}_{2}$ and $\mathrm{NO}_{\mathrm{x}}$ emissions through 2020: PSC (policy success case), REF (reference case), and PFC (policy failure case). Amann et al. (2008) set CLE (current legislation), ACT (advanced control technology) and OPT (a least-cost optimization scenario that would achieve the same health benefit as ACT) cases to analyze the effects of control strategies on the emissions. Cofala et al. (2012) based their study on CPS, NPS, HE (high energy efficiency scenario), and $450 \mathrm{~S}$ from the IEA to analyze the effects of energy path, with few revisions from recent domestic information that is included in this work. Xing et al. (2011a), B. Zhao et al. (2013) and S. X. Wang et al. (2014) devised energy (REF/BAU/PC)-emission control (0/1/2) combination cases to evaluate the possible trends of air pollutants in the future. Since those three studies follow the same methods, we merge the results and refer to them as "Tsinghua" in Fig. 4. The results of the above-mentioned studies are compared with this work for $\mathrm{SO}_{2}, \mathrm{NO}_{\mathrm{x}}$, and $\mathrm{PM}_{2.5}$ emissions, as shown in Fig. 4a, b and c, respectively.
Given the different energy and emission control assumptions, clear differences exist among these studies for projections of China's future emissions of primary air pollutants. However, this work and other studies share some common judgments: (1) the growth of China's primary air pollutant emissions could be constrained through implementation of pollution control strategies in the country, and (2) improved control strategies will play a more important role in emission abatement than variations in possible energy paths, as indicated by the larger differences between scenarios in Amann et al. (2008) than those in Cofala et al. (2012). In most cases, the emissions estimated in this work are higher than similar cases from other studies. As shown in Fig. 4b, for example, the $\mathrm{NO}_{\mathrm{x}}$ emissions in BAU1 and PC1 by Tsinghua in 2020 are 28 and $39 \%$ lower than those in NPS-REF and 450SREF of this work, respectively, and the analogous values in 2030 would be 31 and $38 \%$. The most probable reason for this is that more conservative $\mathrm{NO}_{\mathrm{x}}$ removal efficiencies of LNB, SCR, and SNCR are applied in this work, attributed to the unclear overall operational conditions of those devices at the national level, as described in Sect. 4.2. There are relatively few studies that include $\mathrm{PM}_{2.5}$ because of the higher methodological complexity of its projection than that of other 
pollutants. Lower emissions are found for this work than those by Cofala et al. (2012), possibly due to the use of unabated emission factors and removal efficiencies for several dust collector technologies based on recent domestic measurements by the authors (e.g., Zhao et al., 2010).

\subsection{Emission control: the imperative to broaden the disproportionate focus on coal-fired power, cement, and iron and steel sectors}

For a long time, China's serious air pollution has been strongly associated with its heavy dependence on coal use for industrial production and electricity generation. Almost half of China's coal is consumed by the coal-fired power sector (CPP), and the coal-fired fraction of total electricity has remained relatively stable at approximately $80 \%$. Compiling information at the level of generating units to estimate emissions, the $\mathrm{SO}_{2}, \mathrm{NO}_{\mathrm{x}}$, and $\mathrm{PM}_{10}$ emissions from CPP increased by 49,64 , and $7 \%$ from 2000 to 2005 (Zhao et al., 2008), and CPP accounted for 52, 36, and $11 \%$ of national emissions of those pollutants in 2005, respectively (Y. Zhao et al., 2013). Given these large shares of air pollutant emissions, CPP has been considered the most important target for emission control across the country since 2005 and great efforts have been made to reduce the emissions from electricity generation. Compulsory requirements in energy conservation and emission control have also been implemented in certain major industrial sources other than CPP, including cement (CEM) and iron and steel production (ISP). To evaluate the effectiveness of the policies targeting large sources, the historical emissions of those sectors and shares of national totals from 2000 to 2012 are analyzed and compared with future trends projected in this work. The historical data come from various sources that follow the same bottom-up emission inventory principles: emissions from CPP are estimated with unit-based information from Zhao et al. (2008); $\mathrm{SO}_{2}, \mathrm{NO}_{\mathrm{x}}$, and $\mathrm{PM}_{10}$ emissions from other sources in 2000-2004 are taken, respectively, from Lu et al. (2011), Zhang et al. (2007) and Lei et al. (2011a); emissions in 2005-2010 are from Y. Zhao et al. (2013); and emissions for 2011 and 2012 are updated following the methodology of Y. Zhao et al. (2013), with the most recent commitment of emission control polices included. For future trends, NPS-REF (the best guess scenario) and NPS-STD (with the best guess of the energy path combined with the most aggressive emission control strategies) are selected for comparison.

Figure 5 shows the annual emissions of $\mathrm{SO}_{2}, \mathrm{NO}_{\mathrm{x}}$ and $\mathrm{PM}_{10}$ for CPP (Fig. 5a) and CPP + CEM + ISP (Fig. 5b) and as well as their shares in total national emissions. It is found that the emissions and fractions of $\mathrm{SO}_{2}$ and $\mathrm{PM}_{10}$ for those concerned sources started decreasing around 2005, reflecting the benefits of national pollution control policies set mainly under the 11th Five Year Plan. Even with tightened controls in CPP, CEM, and ISP, however, no further significant reduction of $\mathrm{SO}_{2}$ and $\mathrm{PM}_{10}$ emissions are expected in

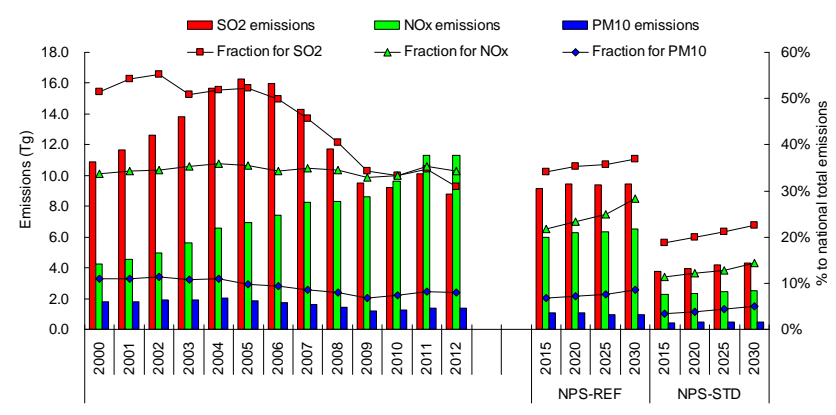

(a)

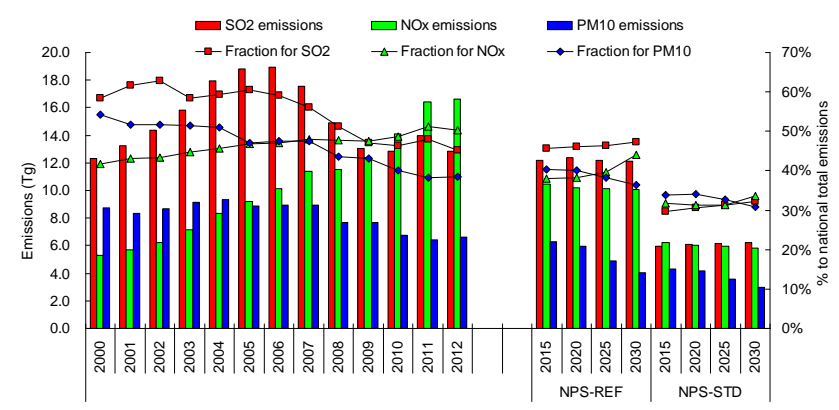

(b)

Figure 5. China's annual emissions (left scale) and fractions of total national emissions (right scale) of given sources ((a) CPP and (b) CPP + CEM + ISP) for 2000-2012 and the projected values for 2015, 2020, 2025 and 2030 under NPS-REF and NPS-STD scenarios

the NPS-REF scenario, and contributions of those sectors to national emissions are estimated to rise again after 2015. The only exception is the emissions of $\mathrm{PM}_{10}$ from CPP + CEM + ISP after 2020. This spotlights the very limited abatement potential remaining in those sectors from a national emission perspective, due to the near saturation of emission control technologies in these industries. For instance, penetration of FGD in the power sector and FF in precalciner cement kilns had reached an estimated 86 and $83 \%$ of total capacity by 2010 , respectively, as discussed earlier. $\mathrm{NO}_{\mathrm{x}}$ emissions from these three sectors increased continuously from 2000 to 2012, but the sharply expanded deployment of SCR and SNCR is expected to lead to considerable abatement in these sectors from 2010 to 2015. Similar to $\mathrm{SO}_{2}$, however, it will become more difficult to reduce $\mathrm{NO}_{\mathrm{x}}$ emissions and national fractions from CPP, CEM, and ISP after 2015 because of saturation of these control technologies. It appears clear that a continued disproportionate focus on the major sources of CPP, CEM, and ISP to achieve the national goals regarding air pollution will be inadequate, under currently projected trends of energy growth, to get anywhere near to the scale of reductions in $\mathrm{SO}_{2}$ emissions achieved from 2005 to 2010. If emission standards can be strictly implemented (NPS-STD in Fig. 5), more abatement of emissions could be achieved for these three sectors, but their emissions and 
fractions would still increase over time despite the aggressive controls. Given the high costs from the improved operation of emission control systems to meet the standards, the STD case is less likely to occur than REF case.

To alleviate China's air pollution effectively in the near future, therefore, it is imperative to broaden the control targets from big sources to other swiftly growing sectors; including building material (brick and lime) production, chemical production, small industrial boilers, and residential stoves. The implementation of energy saving and emission control measures in those sectors will be challenging because of the geographic dispersion of sources and much greater diversities of production technologies. Thus their emissions will often be much harder to monitor and supervise than those of big sources. In order to restrain national emissions and to prevent deteriorating the air quality, however, China has almost no choice but to urgently extend the kind of control measures enacted in CPP, CEM, and ISP to more sectors than ever before.

\subsection{The trends of PM chemical species and their environmental implications}

The future emission trends of PM chemical species, including alkaline dust (calcium $(\mathrm{Ca})$ and magnesium $(\mathrm{Mg})$ ) and carbonaceous aerosols (black carbon (BC) and organic carbon $(\mathrm{OC})$ ), are projected using the methods provided in our previous work (Zhao et al., 2011; Y. Zhao et al., 2013). The emission factor database of PM chemical species is updated particularly for the transportation and residential sectors, combining the most recent field tests (Song et al., 2012; Shen et al., 2013; Wei et al., 2014). It should be noted that the mass fractions of those species for the industrial and transportation sectors have to be assumed constant due to a lack of time-series data from measurements. Uncertainty thus may exist in the projection, and long-term field tests are suggested to support the time-series analysis of emission factor evolution for those species.

As shown in Table 4, significant abatement of anthropogenic alkaline dust emissions is expected in the REF and STD scenarios. As an example, two-thirds of Ca emissions are expected to be cut from 2010 to 2030 in the NSP-REF case. Since the alkaline dust is produced mostly by industrial sources, particularly building material production (cement, lime, and brick), the emissions can be efficiently reduced through the expanded use of advanced dust collectors in those sectors. Fewer benefits are found for carbonaceous aerosols, as the emissions are largely from coal and biofuel combustion in the residential and commercial sectors and biomass open burning. In this work, little progress of emission control is assumed for those sources, and the declines of carbonaceous aerosols result mainly from the decreased use of fossil fuel and biomass burning.

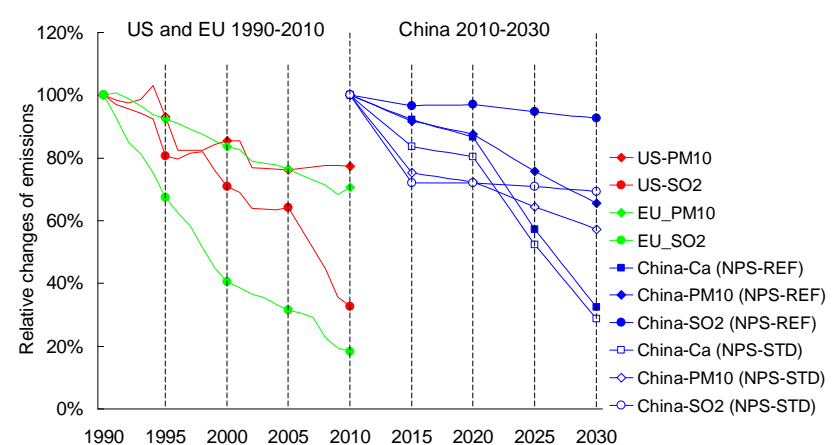

Figure 6. Relative changes of $\mathrm{PM}_{10}$ and $\mathrm{SO}_{2}$ emissions for the US (red) and EU (green) in 1990-2010 and those of $\mathrm{PM}_{10}, \mathrm{Ca}$, and $\mathrm{SO}_{2}$ for China in 2010-2030 under the NPS-REF (solid blue) and NPS-STD (hollow blue) scenarios in this work.

The reduced alkaline dust may increase the risks of ecosystem acidification, as the acid-neutralizing capacity would likely decrease as a result. Illustrated in Fig. 6 are the relative changes of China's $\mathrm{Ca}, \mathrm{PM}_{10}$, and $\mathrm{SO}_{2}$ emissions from 2010 to 2030 for two selected scenarios in this work, NPS-REF and NPS-STD. For comparison, the analogous data on $\mathrm{PM}_{10}$ and $\mathrm{SO}_{2}$ emissions for the US (USEPA, 2011) and for the European Union (CEIP, 2011) for the period 1990-2010 are shown. In contrast to the greater reductions of $\mathrm{SO}_{2}$ than PM historically in the US and EU, a faster decrease in PM (and thus also Ca) emissions than $\mathrm{SO}_{2}$ is projected for China in the future, implying that recovery of acidification in the country will be a considerable challenge under the current national emission control commitment. Long-term observations at different sites across China have partly confirmed the increased acidity of precipitation and decreased alkaline species, particularly in rural areas (Tang et al., 2010; Wang et al., 2012). As the serious haze and PM pollution is now becoming the biggest focus of air quality improvement, further abatement of primary PM (and thereby alkaline base cations) would gradually lead to clearer skies in urban areas but may exacerbate regional acid deposition, if further reduction of $\mathrm{SO}_{2}$ emissions is constrained.

Besides local and regional conventional air pollution impacts, the future trends of aerosols can affect regional climate as well. In this work the changes of radiative forcing (RF) from trends in China's short-lived species are evaluated as the sum of emission-based constituent global forcing (CGF) of $\mathrm{SO}_{2}, \mathrm{NO}_{\mathrm{x}}, \mathrm{BC}$, and $\mathrm{OC}$, weighted by the changes in China's emissions as percentages of total global emissions, following the methods of Carmichael et al. (2002). The emission-based CGF represents that emissions of a single primary precursor can affect several related forcing agents, and the values are taken from Carmichael et al. (2002) and IPCC (2007). It should be acknowledged that the forcing efficacy from those short-lived species is assumed constant for a rough estimate. Figure 7 shows the effects of changes in Chinese emissions between 2005 and 2030 on radiative 
Table 4. Projected national emissions of chemical species of PM (Ca, Mg, BC, and OC) for 2015, 2020, 2025 and 2030 by scenario (unit: $\mathrm{Gg}$ ). The emissions of 2010 (Y. Zhao et al., 2013) are listed as well for comparison

\begin{tabular}{rlrrrrrrrrrrrrrr}
\hline & & 2010 & & 2015 & & & 2020 & & & 2025 & & & 2030 \\
\hline & & & BAS & REF & STD & BAS & REF & STD & BAS & REF & STD & BAS & REF & STD \\
Ca & CPS & 4253 & 4581 & 3929 & 3561 & 4840 & 3705 & 3436 & 4263 & 2479 & 2265 & 4004 & 1426 & 1258 \\
& NPS & & 4570 & 3919 & 3552 & 4819 & 3687 & 3420 & 4212 & 2435 & 2227 & 3946 & 1377 & 1219 \\
& $450 S$ & & 4561 & 3911 & 3544 & 4808 & 3678 & 3412 & 4157 & 2387 & 2184 & 3884 & 1324 & 1173 \\
\hline Mg & CPS & \multirow{2}{*}{356} & 397 & 355 & 255 & 418 & 354 & 258 & 399 & 296 & 222 & 383 & 241 & 185 \\
& NPS & & 394 & 353 & 253 & 413 & 349 & 254 & 387 & 284 & 213 & 369 & 228 & 176 \\
& 450S & & 392 & 351 & 251 & 410 & 347 & 252 & 374 & 273 & 203 & 354 & 215 & 165 \\
\hline BC & CPS & 1667 & 1717 & 1627 & 1341 & 1658 & 1534 & 1260 & 1600 & 1421 & 1196 & 1505 & 1282 & 1117 \\
& NPS & & 1688 & 1599 & 1316 & 1616 & 1495 & 1225 & 1523 & 1343 & 1132 & 1429 & 1199 & 1058 \\
& 450S & & 1650 & 1562 & 1285 & 1599 & 1479 & 1209 & 1458 & 1280 & 1075 & 1352 & 1123 & 991 \\
\hline \multirow{2}{*}{ OC } & CPS & 2848 & 2885 & 2729 & 2460 & 2782 & 2580 & 2325 & 2630 & 2323 & 2118 & 2423 & 2037 & 1891 \\
& NPS & & 2853 & 2699 & 2433 & 2745 & 2547 & 2294 & 2550 & 2254 & 2060 & 2346 & 1968 & 1841 \\
& $450 S$ & & 2829 & 2677 & 2415 & 2726 & 2530 & 2277 & 2467 & 2179 & 1989 & 2262 & 1894 & 1774 \\
\hline
\end{tabular}

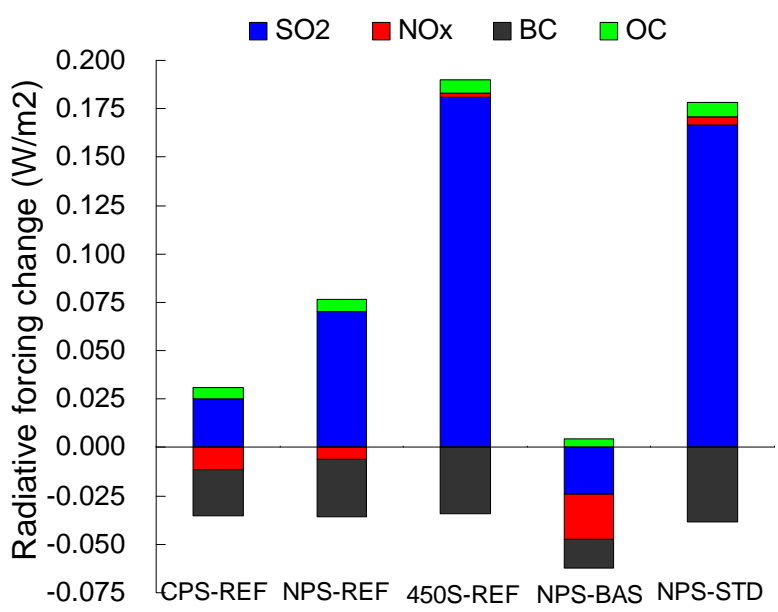

Figure 7. Effects of changes in China's emissions of air pollutants from 2005 to 2030 on radiative forcing for selected scenarios analyzed in this work.

forcing for five scenarios. Three of them: best guess (NPSREF), CPS-REF, and 450-REF evaluate the effects of energy paths. The other two: NPS-BAS and NPS-STD demonstrate the effects of control strategies. Global emissions of $\mathrm{SO}_{2}$ and $\mathrm{NO}_{\mathrm{x}}$ in CPS, NPS, and 450S are obtained from Cofala et al. (2012), while those of carbonaceous aerosols are from Klimont et al. (2014). The latter applies the same methodology as Klimont et al. (2009) and Bond et al. (2013). Emissions from global biomass open burning are taken from Bond et al. (2004).

As shown in Fig. 7, the reduced primary carbonaceous emissions play similar roles in RF change from CPS-REF to 450S-REF, as the fossil fuel energy paths (driven by industrial and power generation demand) have limited effects on $\mathrm{BC}$ and $\mathrm{OC}$ emissions. The warming effects of $\mathrm{SO}_{2}$ reduction are expected to increase, as the emissions would be reduced resulting from reduced coal combustion. Under a common energy path (NPS), both the cooling effects from BC reduction and warming effects from $\mathrm{SO}_{2}$ reduction are expected to grow with the improved implementation of emission controls. The $\mathrm{SO}_{2}$ reduction would dominate the RF changes because current emission control commitments and standards focus little on the residential coal and biofuel combustion that generates most of the carbonaceous aerosols. The tightened controls in China are thus expected to result in enhanced RF in the future. Efforts to reduce emissions from the dispersed residential sources such as small coal and biofuel stoves would not only lead to improved local and regional air quality, but also help limit regional warming from short-lived climate forcing.

\section{Conclusions}

Given the high frequency of serious haze and heavy urban and regional air pollution events, China has announced a national action plan of air pollution control, and a series of measures aimed at energy conservation and emission reduction will be implemented in the coming years. The effectiveness and benefits of those measures on future national emission abatement are evaluated in this work using scenarios coupling different levels of energy consumption with several emission control strategies. Should current policy commitments be implemented, China's primary pollutant emissions are expected to be restrained in the future, including emissions of $\mathrm{NO}_{\mathrm{x}}$ that have grown almost continuously in recent years. However, compromised operational conditions of swiftly disseminating air pollutant control devices (e.g., SCR systems) lead to lower removal efficiencies of air pollutants than expected, and thus partly undermine the benefits 
of emission abatement in the near future, as suggested by satellite-retrieved $\mathrm{NO}_{2}$ vertical column densities observed across the country. Compared to the energy path, the levels of emission control implementation will play more important roles in future trends of emissions for all of the concerned pollutants, particularly for primary aerosols that depend largely on noncombustion industrial processes. Should the emission standards across sectors that have been either issued or proposed be fully met, they could prove highly effective for emission abatement.

Limitations exist for current policy commitments and emission standards. Because of high penetration of emission control devices in key sectors in recent years, the potential for further emission reductions from those sources may be limited despite aggressive control efforts. Therefore, greater efforts should be made to target the small coal and biofuel combustion stoves that generate significantly more fine particles and carbonaceous aerosols than large, energy-efficient boilers, resulting in benefits both to air quality and regional climate. As it is becoming more and more difficult to further reduce $\mathrm{SO}_{2}$, the swift declines in alkaline dust emissions in the future would likely increase acidification risks to ecosystems, as indicated by long-term observations at a number of sites. Thus not only the total amounts of emissions but also the linkages between emissions and various environmental impacts need to be comprehensively considered in policy making. Finally, the highly imbalanced economic development and urbanization by region in China are currently leading to major differences in atmospheric pollution and control strategies across the country. Limited data preclude a better understanding of the regional differentiation with future technology innovation, emission control plans, and thereby emission trends. Further investigations of emission source changes and their spatial distributions are thus urgently needed to reduce uncertainties in the analysis of future emission trends and related impacts, and to better support air pollution control planning across the country.

\section{The Supplement related to this article is available online at doi:10.5194/acp-14-8849-2014-supplement.}

Acknowledgements. This work was sponsored by the Natural Science Foundation of China (41205110), Natural Science Foundation of Jiangsu (BK20140020 and BK2012310), the Ministry of Science and Technology of China (2011BAK21B00), the China Sustainable Energy Program of the Energy Foundation, and the Collaborative Innovation Center for Regional Environmental Quality. We would like to thank Shigeru Suehiro of the International Energy Agency for providing the Chinese energy and industrial projection data, Janusz Cofala from the International Institute for Applied System Analysis for providing the predicted $\mathrm{BC}$ and $\mathrm{OC}$ emission data, and Yu Lei from the Chinese Academy for Environmental Planning for providing China's historical PM emission data. Thanks should also go to TEMIS for free use of their monitoring data, and to two anonymous referees for their very careful and valuable comments to improve this work.

Edited by: N. Riemer

\section{References}

Anshan Iron and Steel Group Corporation (AISGC): The explanation for emission standard of air pollutants for iron and steel industry-sintering, Internal Report, Beijing, China, 2007 (in Chinese).

Amann, M., Jiang, K. J., Hao, J. M., and Wang, S. X.: Scenarios for cost-effective control of air pollution and greenhouse gases in China, International Institute for Applied Systems Analysis, Laxenburg, Austria, 2008.

Baosteel Group Corporation (BGC): The explanation for emission standard of air pollutants for iron and steel industry-steel smelting, Internal Report, Beijing, China, 2007 (in Chinese).

Boersma, K. F., Eskes, H. J., Veefkind, J. P., Brinksma, E. J., van der A, R. J., Sneep, M., van den Oord, G. H. J., Levelt, P. F., Stammes, P., Gleason, J. F., and Bucsela, E. J.: Near-real time retrieval of tropospheric $\mathrm{NO}_{2}$ from OMI, Atmos. Chem. Phys., 7, 2103-2118, doi:10.5194/acp-7-2103-2007, 2007.

Bond, T. C., Streets, D. G., Yarber, K. F., Nelson, S. M., Woo, J.-H., and Klimont, Z.: A technology-based global inventory of black and organic carbon emissions from combustion. J. Geophys. Res., 109, D14203, doi:10.1029/2003JD003697, 2004.

Bond, T. C., Doherty, S. J., Fahey, D. W., Forster, P. M., Berntsen, T., DeAngelo, B. J., Flanner, M. G., Ghan, S., Kärcher, B., Koch, D., Kinne, S., Kondo, Y., Quinn, P. K., Sarofim, M. C., Schultz, M. G., Schulz, M., Venkataraman, C., Zhang, H., Zhang, S., Bellouin, N., Guttikunda, S. K., Hopke, P. K., Jacobson, M. Z., Kaiser, J. W., Klimont, Z., Lohmann, U., Schwarz, J. P., Shindell, D., Storelvmo, T., Warren, S. G., and Zender, C. S.: Bounding the role of black carbon in the climate system: a scientific assessment, J. Geophys. Res., 118, 5380-5552, 2013.

Carmichael, G. R., Streets, D. G., Calori, G., Amann, M., Jacobson, M. Z., Hansen, J., and Ueda, H.: Changing trends in sulfur emissions in Asia: implications for acid deposition, air pollution, and climate, Environ. Sci. Technol., 36, 4707-4713, 2002.

Centre on Emission Inventories and Projections (CEIP): Officially reported emission data, available at: http://www.ceip.at/ webdab-emission-database/officially-reported-emission-data/ (last access: 20 March 2014), 2011. 
Chen, D., Wang, Y., McElroy, M. B., He, K., Yantosca, R. M., and Le Sager, P.: Regional CO pollution and export in China simulated by the high-resolution nested-grid GEOS-Chem model, Atmos. Chem. Phys., 9, 3825-3839, doi:10.5194/acp-9-3825-2009, 2009.

Chinese Research Academy of Environmental Sciences (CRAES): The explanation for emission standard of pollutants for copper, nickel, cobalt industry (in Chinese), available at: http://www.mep.gov.cn/gkml/zj/bgth/200910/ W020071128478677308568.pdf (last access: 20 March 2014), 2007.

Chinese Research Academy of Environmental Sciences (CRAES): The explanation for emission standard of air pollutants for brick industry (in Chinese), available at: http://www.zhb.gov.cn/gkml/ hbb/bgth/200912/W020091202540222872323.pdf (last access: 20 March 2014), 2009.

Cofala, J., Bertok, I., Borken-Kleefeld, J., Heyes, C., Klimont, Z., Rafaj, P., Sander, R., and Schopp, W.: Emissions of Air Pollutants for the World Energy Outlook 2012 Energy Scenarios 2012, Draft Final Report, Contract No. 12-129, International Institute for Applied System Analysis, Laxenburg, Austria, 2012.

Fu, M., Ge, Y., Tan, J., Zeng, T., and Liang, B.: Characteristics of typical non-road machinery emissions in China by using portable emission measurement system, Sci. Total Environ.,437, 255261, 2012.

He, Q. S.: Composite characteristics, emission factors, and emission estimates of particulates and volatile organic compound from coke making in China, Doctoral Thesis, Chinese Academy of Sciences, Beijing, China, 2006.

Huo, H., Wang, M., Zhang, X. L., He, K. B., Gong, H. M., Jiang, K. J., Jin, Y. F., Shi, Y. D., and Yu, X.: Projection of energy use and greenhouse gas emissions by motor vehicles in China: policy options and impacts, Energ. Policy, 43, 37-48, 2012a.

Huo, H., Lei, Y., Zhang, Q., Zhao, L. J., and He, K. B.: China's coke industry: recent policies, technology shift, and implication for energy and the environment, Energ. Policy, 51, 397-404, $2012 \mathrm{~b}$.

Huo, H., Yao, Z., Zhang, Y., Shen, X., Zhang, Q., and He, K.: Onboard measurements of emissions from diesel trucks in five cities in China, Atmos. Environ., 54, 159-167, 2012c.

International Energy Agency (IEA): World Energy Outlook 2012, International Energy Agency, Paris, France, 2012.

Intergovernmental Panel on Climate Change (IPCC): Climate change 2007 - the physical science basis, Contribution of working group I to the fourth assessment report of the IPCC, New York, USA, 2007.

Kan, H. D., Chen, R. J., Tong, S. L.: Ambient air pollution, climate change, and population health in China, Environ. Int., 42, 10-19, 2012

Klimont, Z., Kupiainen, K., Heyes, Ch., Purohit, P., Cofala, J., Rafaj, P., and Schopp, W.: Global anthropogenic emissions of particulate matter, in preparation, 2014.

Klimont, Z., Cofala, J., Xing, J., Wei, W., Zhang, C. Y., Wang, S. X., Jiang, K. J., Bhandari, P., Mathur, R., Purohit, P., Rafaj, P., Chambers, A., and Amann, M: Projections of $\mathrm{SO}_{2}, \mathrm{NO}_{\mathrm{x}}$, and carbonaceous aerosols emissions in Asia, Tellus B, 61, 602-617, 2009.

Klimont, Z., Cofala, J., Schopp, W., Amann, M., Streets, D. G., Ichikawa, Y., and Fujita, S.: Projections of $\mathrm{SO}_{2}, \mathrm{NO}_{\mathrm{x}}, \mathrm{NH}_{3}$ and VOC emissions in East Asia up to 2030, Water Air Soil Poll., 130, 193-198, 2001
Larssen, T., Lydersen, E., Tang, D. G., He, Y., Gao, J. X., Liu, H. Y., Duan, L., Seip, H. M., Vogt, R. D., Mulder, J., Shao, M., Wang, Y. H., Shang, H., Zhang, X. S., Solberg, S., Aas, W., Okland, T., Eilertsen, O., Angell, V., Liu, Q. R., Zhao, D. W., Xiang, R. J., Xiao, J. S., and Luo, J. H.: Acid rain in China, Environ. Sci. Technol., 40, 418-425, 2006.

Lei, Y., Zhang, Q., He, K. B., and Streets, D. G.: Primary anthropogenic aerosol emission trends for China, 1990-2005, Atmos. Chem. Phys., 11, 931-954, doi:10.5194/acp-11-931-2011, 2011a.

Lei, Y., Zhang, Q., Nielsen, C. P., and He, K. B.: An inventory of primary air pollutants and $\mathrm{CO}_{2}$ emissions from cement industry in China, 1990-2020, Atmos. Environ., 45, 147-154, $2011 \mathrm{~b}$.

Li, C., Zhang, Q., Krotkov, N. A., Streets, D. G., He, K. B., Tsay, S. C., and Gleason, J. F.: Recent large reduction in sulfur dioxide emissions from Chinese power plants observed by the Ozone Monitoring Instrument, Geophys. Res. Lett., 37, L08807, doi:10.1029/2010GL042594, 2010.

Li, D. L.: Study on emission inventory of non-road mobile sources in China, Master Thesis, Tsinghua University, Beijing, China, 2011.

Lin, J. T., Nielsen, C. P., Zhao, Y., Lei, Y., Liu, Y., and McElroy, M. B.: Recent changes in particulate air pollution over China observed from space and the ground: effectiveness of emission control, Environ. Sci. Technol., 44, 7771-7776, 2010.

Lu, Z., Streets, D. G., Zhang, Q., Wang, S., Carmichael, G. R., Cheng, Y. F., Wei, C., Chin, M., Diehl, T., and Tan, Q.: Sulfur dioxide emissions in China and sulfur trends in East Asia since 2000, Atmos. Chem. Phys., 10, 6311-6331, doi:10.5194/acp-106311-2010, 2010.

Lu, Z., Zhang, Q., and Streets, D. G.: Sulfur dioxide and primary carbonaceous aerosol emissions in China and India, 1996-2010, Atmos. Chem. Phys., 11, 9839-9864, doi:10.5194/acp-11-98392011, 2011.

Ma, J. Z., Xu, X. B., Zhao, C. S., and Yan, P.: A review of atmospheric chemistry research in China: photochemical smog, haze pollution, and gas-aerosol interactions, Adv. Atmos. Sci., 29, 1006-1026, 2012.

Matus, K., Nam, K. M., Selin, N. E., Lamsal, L. N., Reilly, J. M., and Paltsev, S.: Health damages from air pollution in China, Global Environ. Chang., 22, 55-66, 2012.

Ministry of Environmental Protection in China (MEP): The handbook of emission factors of industrial sources for the first national survey on pollutant sources, Beijing, China, 2010 (in Chinese).

Ohara, T., Akimoto, H., Kurokawa, J., Horii, N., Yamaji, K., Yan, X., and Hayasaka, T.: An Asian emission inventory of anthropogenic emission sources for the period 1980-2020, Atmos. Chem. Phys., 7, 4419-4444, doi:10.5194/acp-7-4419-2007, 2007.

Ou, X., Zhang, X., and Chang, S.: Scenario analysis on alternative fuel/vehicle for China's future road transport: life-cycle energy demand and GHG emissions, Energ. Policy, 38, 3943-3956, 2010.

Parrish, D. D. and Zhu, T.: Clean air for megacities, Science, 326, 674-675, 2009

Qiu, L., Zhao Y., Xu, R., Xie F., Wang, H., Wu, X., Qin, H., and Zhang, J.: Assessment of city-scale high-resolution emission in- 
ventory of anthropogenic atmospheric pollutants: a case study of Nanjing, the host city of 2nd YOG, in preparation, 2014.

Richter, A., Burrows, J. P., Nuss, H., Granier, C., and Niemeier, U.: Increase in tropospheric nitrogen dioxide over China observed from space, Nature, 437, 129-132, 2005.

Shen, G., Tao, S., Wei, S., Chen, Y., Zhang, Y., Shen, H., Huang, Y., Zhu, D., Yuan, C., Wang H., Wang, Y., Pei, L., Liao, Y., Duan, Y., Wang, B., Wang, R., Lv, Y., Li, W., Wang, X., and Zheng, X.: Field measurement of emission factors of PM, EC, OC, parent, nitro, and oxy-polycyclic aromatic hydrocarbons for residential briquette, coal cake, and wood in rural Shanxi, China, Environ. Sci. Technol., 47, 2998-3005, 2013.

Sinosteel Corporation (SSC): The explanation for emission standard of air pollutants for iron and steel industry-iron making, Internal Report, Beijing, China, 2007 (in Chinese).

Song, W. W., He, K. B., and Lei, Y.: Black carbon emissions from on-road vehicles in China, 1990-2030, Atmos. Environ., 51, 320-328, 2012.

Streets, D. G. and Waldhoff, S. T.: Present and future emissions of air pollutants in China: $\mathrm{SO}_{2}, \mathrm{NO}_{\mathrm{x}}$, and $\mathrm{CO}$, Atmos. Environ., 34, 363-374, 2000.

Tang, J., Xu, X. B., Ba, J., and Wang, S. F.: Trends of the precipitation acidity over China during 1992-2006, Chinese. Sci. Bull., 55, 1800-1807, 2010.

US Environmental Protection Agency (USEPA): Emission inventory information, available at: http:/www.epa.gov/ttn/chief/ trends/index.html (last access: 20 March 2014), 2011.

van Donkelaar, A., Martin, R. V., Brauer, M., Kahn, R., Levy, R., Verduzco, C., and Villeneuve, P. J.: Global estimates of ambient fine particulate matter concentrations from satellite-based aerosol optical depth: development and application, Environ. Health Persp., 118, 847-855, 2010.

Wang, F.: The control policy for total emission amount of primary pollutants during the 12th Five Year Plan period, presented at the 17th Workshop on $\mathrm{SO}_{2}, \mathrm{NO}_{\mathrm{x}}$, and $\mathrm{Hg}$ pollution control technology and $\mathrm{PM}_{2.5}$ control and monitoring technology, Hangzhou, China, 16-17 May, 2013.

Wang, L. T., Wei, Z., Yang, J., Zhang, Y., Zhang, F. F., Su, J., Meng, C. C., and Zhang, Q.: The 2013 severe haze over southern Hebei, China: model evaluation, source apportionment, and policy implications, Atmos. Chem. Phys., 14, 3151-3173, doi:10.5194/acp-14-3151-2014, 2014.

Wang, M., Huo, H., Johnson, L., and He, D.: Projection of Chinese motor vehicle growth, oil demand, and $\mathrm{CO}_{2}$ emissions through 2050, Argonne National Laboratory, ANL/ESD/06-6, Illinois, USA, 2006.

Wang, S. X. and Hao, J. M.: Air quality management in China: issues, challenges, and options, J. Environ. Sci., 24, 2-13, 2012.

Wang, S. X., Zhao, M., Xing, J., Wu, Y., Zhou, Y., Lei, Y., He, K. B., Fu, L. X., and Hao, J. M.: Quantifying the air pollutants emission reduction during the 2008 Olympic Games in Beijing, Environ. Sci. Technol., 44, 2490-2496, 2010.

Wang, S. X., Xing, J., Jang, C., Zhu, Y., Fu, J. S., and Hao, J. M.: Impact assessment of ammonia emissions on inorganic aerosols in east China using response surface modeling technique, Environ. Sci. Technol., 45, 9293-9300, 2011.

Wang, S. X., Zhao, B., Cai, S. Y., Klimont, Z., Nielsen, C., McElroy, M. B., Morikawa, T., Woo, J. H., Kim, Y., Fu, X., Xu, J. Y., Hao, J. M., and He, K. B.: Emission trends and mitigation options for air pollutants in East Asia, Atmos. Chem. Phys. Discuss., 14, 2601-2674, doi:10.5194/acpd-14-2601-2014, 2014.

Wang, Y. S., Yao, L., Wang, L. L., Liu, Z. R., Ji, D. S., Tang, G. Q., Zhang, J. K., Sun, Y., Hu, B., and Xin, J. Y.: Mechanism for the formation of the January 2013 heavy haze pollution episode over central and eastern China, Sci. China Ser. D, 57, 14-25, 2014.

Wang, Y. S., Yu, W. P., Pan, Y. P., and Wu, D.: Acid neutralization of precipitation in Northern China, J. Air Waste Manage., 62, 204-211, 2012.

Wang, Y., Hao, J., McElroy, M. B., Munger, J. W., Ma, H., Chen, D., and Nielsen, C. P.: Ozone air quality during the 2008 Beijing Olympics: effectiveness of emission restrictions, Atmos. Chem. Phys., 9, 5237-5251, doi:10.5194/acp-9-5237-2009, 2009.

World Bank (WB) and State Environmental Protection Administration (SEPA): Cost of pollution in China, Rural Development, Natural Resources and Environment Management Unit, East Asia and Pacific Region, The World Bank, Washington DC, available at: http://www.worldbank.org/eapenvironment (last access: 20 March 2014), 2007.

Wei, S., Shen, G., Zhang, Y., Xue, M., Xie, H., Lin, P., Chen, Y., Wang, X., and Tao, S.: Field measurement on the emissions of PM, OC, EC and PAHs from indoor crop straw burning in rural China, Environ. Pollut., 184, 18-24, 2014.

Xing, J., Wang, S. X., Chatani, S., Zhang, C. Y., Wei, W., Hao, J. M., Klimont, Z., Cofala, J., and Amann, M.: Projections of air pollutant emissions and its impacts on regional air quality in China in 2020, Atmos. Chem. Phys., 11, 3119-3136, doi:10.5194/acp-113119-2011, 2011a.

Wu, J. R.: The perspective for power industry 2012-2050, National Energy Administration, internal report, available at: http://www. cpnn.com.cn/, 2013 (in Chinese).

Wu, Y., Zhang, S. J., Li, M. L., Ge, Y. S., Shu, J. W., Zhou, Y., $\mathrm{Xu}$, Y. Y., Hu, J. N., Liu, H., Fu, L. X., He, K. B., and Hao, J. M.: The challenge to $\mathrm{NO}_{\mathrm{x}}$ emission control for heavyduty diesel vehicles in China, Atmos. Chem. Phys., 12, 93659379, doi:10.5194/acp-12-9365-2012, 2012.

Xing, J., Wang, S. X., Jang, C., Zhu, Y., and Hao, J. M.: Nonlinear response of ozone to precursor emission changes in China: a modeling study using response surface methodology, Atmos. Chem. Phys., 11, 5027-5044, doi:10.5194/acp-11-5027-2011, 2011b.

$\mathrm{Xu}$, M. and Wang, Y. J.: The potential and countermove of energysaving and cutting pollution about brick and tile industry in China, Brick and Tile World, 7, 6-11, 2007 (in Chinese).

$\mathrm{Xu}$, Y.: Improvements in the operation of $\mathrm{SO}_{2}$ scrubbers in China's coal power plants, Environ. Sci. Technol., 45, 380-385, 2011.

Yao, Z. L., Huo, H., Zhang, Q., Streets, D. G., and He, K. B.: Gaseous and particulate emissions from rural vehicles in China, Atmos. Environ., 45, 3055-3061, 2011.

Zhang, H., Wang, S., Hao, J., Wan, L., Jiang, J., Zhang, M., Mestil, H. E. S., Alnes, L. W. H., Aunan, K., Mellouki, A. W.: Chemical and size characterization of particles emitted from the burning of coal and wood in rural households in Guizhou, China, Atmos. Environ., 51, 94-99, 2012.

Zhang, Q., He, K. B., and Huo, H.: Cleaning China's air, Nature, 484, 161-162, 2012a

Zhang, Q., Geng, G. N., Wang, S. W., Richter, A., and He, K. B.: Satellite remote sensing of changes in $\mathrm{NO}_{\mathrm{x}}$ emissions over 
China during 1996-2010, Chinese Sci. Bull., 57, 2857-2864, doi:10.1007/s11434-012-5015-4, 2012b.

Zhang, Q., Streets, D. G., Carmichael, G. R., He, K. B., Huo, H., Kannari, A., Klimont, Z., Park, I. S., Reddy, S., Fu, J. S., Chen, D., Duan, L., Lei, Y., Wang, L. T., and Yao, Z. L.: Asian emissions in 2006 for the NASA INTEX-B mission, Atmos. Chem. Phys., 9, 5131-5153, doi:10.5194/acp-9-5131-2009, 2009.

Zhang, Q., Streets, D. G., He, K. B., Wang, Y. X., Richter, A., Burrows, J. P., Uno, I., Jang, C. J., Chen, D., Yao, Z. L., and Lei, Y.: $\mathrm{NO}_{\mathrm{x}}$ emission trends for China, 1995-2004: the view from the ground and the view from space, J. Geophys. Res., 112, D22306, doi:10.1029/2007JD008684, 2007.

Zhao, B., Wang, S. X., Liu, H., Xu, J. Y., Fu, K., Klimont, Z., Hao, J. M., He, K. B., Cofala, J., and Amann, M.: $\mathrm{NO}_{\mathrm{x}}$ emissions in China: historical trends and future perspectives, Atmos. Chem. Phys., 13, 9869-9897, doi:10.5194/acp-13-9869-2013, 2013.

Zhao, Y., Wang, S. X., Duan, L., Lei, Y., Cao, P. F., and Hao, J. M.: Primary air pollutant emissions of coal-fired power plants in China: current status and future prediction, Atmos. Environ., 42, 8442-8452, 2008.

Zhao, Y., Duan, L., Xing, J., Larssen, T., Nielsen, C. P., and Hao, J. M.: Soil acidification in China: is controlling $\mathrm{SO}_{2}$ emissions enough, Environ. Sci. Technol., 43, 8021-8026, 2009.
Zhao, Y., Wang, S. X., Nielsen, C. P., Li, X. H., and Hao, J. M.: Establishment of a database of emission factors for atmospheric pollutants from Chinese coal-fired power plants, Atmos. Environ., 44, 1515-1523, 2010.

Zhao, Y., Duan, L., Lei, Y., Xing, J., Nielsen, C. P., and Hao, J. M.: Will PM control undermine China's efforts to reduce soil acidification, Environ. Pollut., 159, 2726-2732, 2011 a.

Zhao, Y., Nielsen, C. P., Lei, Y., McElroy, M. B., and Hao, J.: Quantifying the uncertainties of a bottom-up emission inventory of anthropogenic atmospheric pollutants in China, Atmos. Chem. Phys., 11, 2295-2308, doi:10.5194/acp-11-2295-2011, $2011 \mathrm{~b}$.

Zhao, Y., Nielsen, C. P., McElroy, M. B., Zhang, L., and Zhang, J.: $\mathrm{CO}$ emissions in China: uncertainties and implications of improved energy efficiency and emission control, Atmos. Environ., 49, 103-113, 2012.

Zhao, Y., Zhang, J., and Nielsen, C. P.: The effects of recent control policies on trends in emissions of anthropogenic atmospheric pollutants and $\mathrm{CO}_{2}$ in China, Atmos. Chem. Phys., 13, 487-508, doi:10.5194/acp-13-487-2013, 2013. 